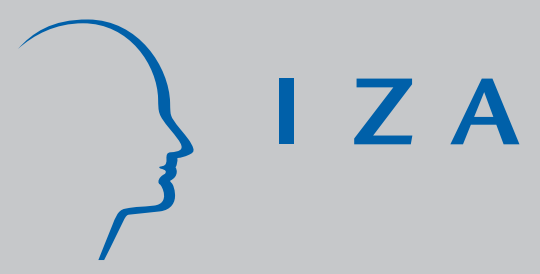

IZADP No. 4021

An Innovation Index Based on Knowledge Capital Investment: Definition and Results for the UK Market Sector

Tony Clayton

Mariela Dal Borgo

J onathan Haskel

February 2009 


\title{
An Innovation Index Based on Knowledge Capital Investment: Definition and Results for the UK Market Sector
}

\author{
Tony Clayton \\ Office of National Statistics
}

Mariela Dal Borgo

University of Warwick

Jonathan Haskel

Imperial College Business School, CEPR, CeRIBA and IZA

Discussion Paper No. 4021

February 2009

\author{
IZA \\ P.O. Box 7240 \\ 53072 Bonn \\ Germany \\ Phone: +49-228-3894-0 \\ Fax: +49-228-3894-180 \\ E-mail: iza@iza.org
}

Any opinions expressed here are those of the author(s) and not those of IZA. Research published in this series may include views on policy, but the institute itself takes no institutional policy positions.

The Institute for the Study of Labor (IZA) in Bonn is a local and virtual international research center and a place of communication between science, politics and business. IZA is an independent nonprofit organization supported by Deutsche Post Foundation. The center is associated with the University of Bonn and offers a stimulating research environment through its international network, workshops and conferences, data service, project support, research visits and doctoral program. IZA engages in (i) original and internationally competitive research in all fields of labor economics, (ii) development of policy concepts, and (iii) dissemination of research results and concepts to the interested public.

IZA Discussion Papers often represent preliminary work and are circulated to encourage discussion. Citation of such a paper should account for its provisional character. A revised version may be available directly from the author. 


\title{
ABSTRACT \\ An Innovation Index Based on Knowledge Capital Investment: Definition and Results for the UK Market Sector ${ }^{*}$
}

\begin{abstract}
We (a) propose an implementable innovation index, (b) relate it to existing innovation definitions and (c) show whole-economy and industry-specific results for the UK market sector, 2000-2005. Our innovation measure starts by observing that we could get more GDP without innovation by simply duplicating existing physical capital and labour (e.g. adding a second aircraft and crew on an existing route). Thus we propose to measure innovation as the additional GDP over and above the addition existing physical capital and labour. In our measure this is the contribution to GDP growth of market sector investment in knowledge (or intangible) capital. This contribution is measured from company spending on knowledge/intangible assets and TFP growth. We relate our measure to the literature on innovation definitions, TFP, creative industries and hidden innovation. We implement it for six UK market sector industries, 2000-2005, combining with output and tangible investment data from the EUKLEMS database. Our main findings are as follows. Over 2000-2005, market sector labour productivity grew at $2.74 \%$ per annum, of which the contribution of knowledge capital, our innovation measure, was $1.24 \%$ pa. In turn, manufacturing accounted for about $60 \%$ of this latter figure. If one includes increase in labour skill deepening $(0.45 \% \mathrm{pa})$ as innovation, then innovation contributed $61 \%(=(1.24+0.45) / 2.74)$ of labour productivity growth over the period.
\end{abstract}

JEL Classification: O47, E22, E01

Keywords: innovation, productivity growth

Corresponding author:

Jonathan Haskel

Imperial College Business School

Imperial College

London SW7 2AZ

United Kingdom

E-mail: j.haskel@ic.ac.uk

\footnotetext{
* We are very grateful for financial support for this research from a NESTA Summer 2008 Project award and the COINVEST project, www.coinvest.org.uk, funded by the European Commission FP7, Theme 9, Socio-economic Science and Humanities, grant number 217512. This paper is a shortened version of Clayton, Dal Borgo and Haskel (2008) which contains more discussion as indicated in this paper. It builds on previous work financed by BERR and was carried out at CeRiBA at the Business Data Linking Branch at the ONS; we are grateful to all institutions concerned for their support. This work contains statistical data from ONS which is crown copyright and reproduced with the permission of the controller HMSO and Queen's Printer for Scotland. The use of the ONS statistical data in this work does not imply the endorsement of the ONS in relation to the interpretation or analysis of the statistical data. The results in section 4 are drawn from Mariela dal Borgo's M.Sc Economics thesis at the University of Warwick. All errors are of course our own.
} 


\section{Introduction ${ }^{1}$}

A number of agencies have been charged with investigating and developing an innovation index. NESTA (the National Endowment for Science Technology and the Arts) in the UK is obliged to develop an index in 2010. An Advisory Committee to the US Commerce Department, including the CEOs of Microsoft, UPS and 3M have investigated the issue for the US (Innovation Measurement, 2008). The OECD are examining this question en route to an innovation strategy.

There are three main current approaches to such an index. The first is to propose a definition of innovation and then produce an index. Thus far however whilst there are plenty of proposals there are rather fewer implementations of such proposals. The second approach is the reverse, namely to calculate an index and assume (explicitly or implicitly) it is innovation. The third is to suspend the notion of an index altogether and do something else (Innovation Measurement, 2008).

The aim of this paper is pragmatic, namely to move toward producing an index (or to produce some unimpeachable logic on why it cannot be done). This imposes the constraint that an innovation definition must be implementable with either existing data or data that can be collected quickly. Thus we have three main aims. First, we propose an implementable definition of innovation. Second, we relate it to existing literature. Third, we go to the data and report some preliminary measures of what this definition might look like.

As background, it is worth starting by considering some of the definitions of innovation that have recently been proposed. NESTA (2007) propose "change associated with the creation and adoption of ideas that are new-to-world, new-to-nation/region, new-to-industry or new-to-firm" without being very clear on what "change" is and how it might be measured. The Frascati Manual (2002) proposes "Technological innovation activities are all of the scientific, technological, organisational, financial and commercial steps, including investments in new knowledge, which actually, or are intended to, lead to the implementation of technologically new or improved products and processes" which confines attention to the technology and does not define how "implementation" might be measured. Whilst the Oslo manual broadens the definition to include organisational innovations, "A technological product innovation is the implementation/commercialisation of a product with improved performance characteristics such as to deliver objectively new or improved services to the consumer. A technological process innovation is the implementation/adoption of new or significantly improved production or delivery methods. It may involve changes in equipment, human resources, working methods or a combination of these", it introduces the term "objectively new or improved” without defining it. Finally, the US Advisory Committee propose “ The design, 
invention, development and/or implementation of new or altered products, services, processes, systems, organizational structures, or business models for the purpose of creating new value for customers and financial returns for the firm", which is broad in innovation scope but focuses on commercialised products and so is, as they point out, orientated at a private sector definition.

Many different disciplines are involved in this effort and our approach to the issue is from an economics standpoint. Our definition of innovation is TFP plus the part of capital deepening accounted for by new knowledge investment. It therefore follows the research program set out in the expanded view of capital and TFP measurement proposed by Corrado, Hulten and Sichel (2004, 2006), which builds of course in turn on the work on growth accounting set out for example in the Jorgenson volumes (Jorgenson, 2007). ${ }^{2}$ An important point of this work is that the Corrado, Hulten and Sichel argument that admission of intangible spending as building a knowledge asset requires both the recomputation of inputs, since knowledge/intangible capital is an additional input and also output (value added) since the capitalisation of intangible spending removes it from intermediate spending and so raises value added. Thus both output, inputs and TFP are recalculated relative to the case where intangible spending is treated as an expense. To economists familiar with this work, we hope this paper will still have some interest: we explicitly ask how TFP relates to the many innovation definitions that have been proposed and analyse new data on UK industry TFP and intangible spending (relative to Giorgio Marrano, Haskel and Wallis, 2007, we have new data on design; we use the industry data on intangible investment in Gill and Haskel, 2008, and present industry growth accounting results).

To preview our results, our main findings are as follows. Over 2000-2005, UK market sector labour productivity grew at $2.74 \%$ pa, of which the contribution of knowledge capital, our innovation measure, was $1.24 \%$ pa (of the $1.24 \%$ pa, investment in knowledge assets contributed $1.19 \%$ pa and TFP growth $0.05 \% \mathrm{pa})$. In turn, manufacturing accounted for about $60 \%$ of the $1.24 \%$ pa figure. If one includes increase in labour skill deepening ( $0.45 \%$ pa) as innovation, then innovation contributed $61 \%(=(1.24+0.45) / 2.74)$ of labour productivity growth over the period.

\footnotetext{
${ }^{1}$ See the longer version of this paper, Clayton, Dal Borgo and Haskel (CDH, 2008), for a non-technical summary of this paper, and a fuller discussion of the relation to other innovation definitions, the distinction between knowledge, ideas and technical change and what other data needs to be collected.

${ }^{2}$ The motivation for the index builds on an argument made by Jorgenson (2007) in his evidence to the Gutierrez committee who says "What is the relationship between TFP and innovation? To answer this question it is useful to begin by considering economic growth without innovation. This can take place through expansion of the labor force as the population grows and expansion of capital services through investment in existing technologies. If there is no innovation, output will increase in proportion to the growth in capital and labor inputs. New or altered processes, systems, organizational structures or business models generate growth of output that exceeds the growth of capital and labor inputs. This produces growth of Total Factor Productivity. Total Factor Productivity growth also captures innovation through new and improved products and services. These innovations create new value for consumers and generate financial returns for successful innovators. The new and improved products and services are included in the measures of output. Output expands more than in proportion to the growth of inputs. For example, new computers, telecommunications equipment, and software compete with existing products. If they are successful in penetrating markets for information technology, they are included in the gross domestic product, as well as in the outputs of the industries where the new products and services originate.”
} 
There are of course a number of things that our work does not do. First, as mentioned above, we do not count new ideas. We count the value of the new output stemming from new ideas and we will count investment in new ideas. Second, since we focus on output, we have obvious problems with the hard-to-measure sectors. Thus at the moment we consider it unlikely that we can obtain good indices of the public sector, and many parts of financial services are also likely to be hard. This might be important depending slightly on the degree of disaggregation needed.

Third, it is often argued that an important, possibly the most important, knowledge capital source is education. To the extent that this is paid for by firms, we count it as firm investment. To the extent that it is paid for by the public sector or households, it shows up (albeit somewhat indirectly) via our labour quality measures. ${ }^{3}$ Fourth, our approach of locating innovation via its effect on growth, clearly relies on a number of assumptions, in particular, using, respectively, knowledge capital deepening and TFP as summary measures of the growth impact of new ideas paid and not paid for by firms. For those who find the assumptions in building these measures unacceptable, we do provide data on spending on series of knowledge/intangible assets which should be of interest, (even if the assumptions on the mechanism by which such spending then changes output are of no interest).

The rest of this paper proceeds as follows. Section 2 sets out a formal model of our index and definition, section 3 the relation to other work, section 4 our results and section 5 concludes.

\section{A formal model and definitions}

This section follows CHS and Oliner and Sichel (1990) and sets out a formal model of a three sector economy producing, respectively, intangible/knowledge capital goods, tangible capital goods and consumption goods. The model shows how the incorporation of these assumptions leads to new data for GDP, inputs and TFP and relates these data to innovation. Our main objective in setting out this model is to better understand the motivation for the innovation index, namely the growth in output not explained by growth in tangible capital and labour inputs and how it might be measured.

\subsection{Formal model}

The CHS model assumes three sectors. The final goods sector produces consumption goods, that is goods that have no investment property. The other two sectors produce investment goods, that is goods that create an asset. These sectors produce new tangible capital (I) and new knowledge/intangible capital (N). The tangible capital stock accumulates according to

$$
K_{t}=I_{t}+\left(1-\delta_{K}\right) K_{t-1}
$$

\footnotetext{
${ }^{3}$ As a matter of official National Accounting measurement practice, households are not regarded as producers and so their education spending is not investment.
} 
where $\mathrm{K}$ is the real stock of tangible capital, and I investment in tangible capital. The intangible capital stock is given by $R_{t}$ which also accumulates according to

$$
R_{t}=N_{t}+\left(1-\delta_{R}\right) R_{t-1}
$$

Where $\mathrm{N}$ is the value of new ideas produced in the period. This then captures the notion that new ideas boost the knowledge stock.

All sectors rent tangible and knowledge capital so that their production functions and profit identities can be written

(a) Intangible sector: $N_{t}=F^{N}\left(L_{N, t}, K_{N, t}, R_{N, t}, t\right) ; \quad P_{t}^{N} N_{t}=P_{t}^{L} L_{N, t}+P_{t}^{K} K_{N, t}+P_{t}^{R} R_{N, t}$

(b) Tangible sector: $I_{t}=F^{I}\left(L_{I, t}, K_{I, t}, R_{I, t}, t\right) ; \quad P_{t}^{I} I_{t}=P_{t}^{L} L_{I, t}+P_{t}^{K} K_{I, t}+P_{t}^{R} R_{I, t}$

(c) Consumption sector: $C_{t}=F^{C}\left(L_{C, t}, K_{C, t}, R_{C, t}, t\right) ; \quad P_{t}^{C} C_{t}=P_{t}^{L} L_{C, t}+P_{t}^{K} K_{C, t}+P_{t}^{R} R_{C, t}$

We have excluded from (3) any intermediate goods, such as raw materials that are used up in production. Of course, it is standard in most accounting treatments to treat (most) intangible spending this way as well and we deal with that case below.

We may now write down the following definitions. Nominal GDP and the growth rate of real GDP are defined as

$$
\begin{aligned}
P^{V} V & =P^{C} C+P^{I} I+P^{N} N \\
\Delta \ln V & =\frac{P^{C} C}{P^{V} V} \Delta \ln C+\frac{P^{I} I}{P^{V} V} \Delta \ln I+\frac{P^{N} N}{P^{V} V} \Delta \ln N
\end{aligned}
$$

Where the first term follows from the definition of GDP and the second term is an index number defining real GDP growth. Finally, we assume that all inputs are paid the same across all sectors giving economy-wide definitions as

$$
\begin{aligned}
X & =\sum_{i=C, I, N} X^{i}, \quad X=K, L, N \\
\Delta \ln X & =\sum_{i=C, I, N} \frac{P^{X} X^{i}}{P^{X} X} \Delta \ln X^{i}, \quad X=K, L, N
\end{aligned}
$$

Where the first term simply defines economy-wide employment of input $\mathrm{X}$ to the sum across industries and the second defines the growth of aggregate real inputs as the share-weighted industryspecific growth. 
We are now in a position to write how real aggregate output grows i.e. the relation between increased output and increased human, tangible and intangible inputs. Differentiating the production functions in (3) and substituting the resulting expressions for $\Delta \operatorname{lnC}, \Delta \ln I$ and $\Delta \ln N$ into (4) and using (5) we can write the following the sources of economy-wide value added growth in terms of economywide input growth as the following

$$
\Delta \ln V=s^{K} \Delta \ln K+s^{L} \Delta \ln L+s^{R} \Delta \ln R+\Delta \ln T F P
$$

where

$$
\begin{aligned}
& S^{X}=\left(P^{X} X / P^{V} V\right), \quad X=K, L, R \\
& \Delta \ln T F P=\sum_{Y=C, I, N}\left(\frac{P^{Y} Y}{P^{V} V}\right) \Delta \ln T F P^{Y}, \quad Y=C, I, N
\end{aligned}
$$

Which says that $s^{X}$ terms are the input factor shares of value added, which weight the primary factors, and economy wide value-added TFP growth is the sum of the Domar weighted sector $\Delta \operatorname{lnTFP}$ terms. Equation (6) has the following interpretation. Economy value grows due to primary factors and TFP growth in each sector. The primary inputs in this case are $\mathrm{K}, \mathrm{L}$ and the stock of intangible knowledge R. These growth rates are weighted by the shares of each factor in final output. The TFP growth rates are rates of technical progress in each sector and they are weighted by the ratio of each sector's output to final output Q (Domar weights, Domar, 1961). The Domar weights add to more than unity since a TFP increase in a given sector raises overall TFP by both the direct contribution of the increase plus the indirect contribution of that good into other sectors.

What is the implication of this model for innovation? Equation (6) shows that the economy can grow due to $\Delta \operatorname{lnK}$ and $\Delta \ln L$ i.e. with the addition of more tangible capital and labour alone (at the moment are vague about exactly the definition of output and capital, these are discussed more below). Thus if our innovation index is to exclude this effect, it will be

$$
\begin{aligned}
I I & =\Delta \ln V-\left(s^{K} \Delta \ln K+s^{L} \Delta \ln L\right) \\
& =s^{R} \Delta \ln R+\Delta \ln T F P
\end{aligned}
$$

The intuition behind this expression is as follows. The TFP terms are straightforward since they reflect increases in technical change that raises output for any given inputs (of course in practice they also will incorporate measurement error and the like). The first term on the left hand side, namely the share weighted change in the stock of knowledge is a little more complicated. It consists of the change in the knowledge stock, which as set out in (2), captures the notion the innovation is about the 
growth of ideas. It is weighted by the share term for the following reason. Given our definition, we require a way of converting the $\Delta \operatorname{lnR}$ into extra output. Consider then a firm paying for a new idea (contracting to hire scientists with an R\&D company for example). At its cost minimising point, the cost of knowledge will just equal the extra revenue flow from such knowledge. From this, it can be shown that the proportional effect on output of a proportional change in the knowledge stock is the payments to knowledge as a proportion of total output value.

\subsection{Discussion}

We now discuss some of the features of the model and the issues that it raises, moving term by term in (8).

\subsubsection{Output measure}

First, the whole-economy output measure here is value added. At the industry level, there is case for examining technology using gross output since that allows one to calculate TFP without imposing restrictive conditions on technology. The relation between gross output industry $\triangle \ln T F P$ and overall value added based $\triangle \ln T F P$ is set out below.

Second, it is worth mentioning that other innovation studies have used other output measures such as patents, trademarks or answers to innovation questions. Some have criticised such measures as being too narrow but we take no stand on this matter here. This framework says nothing about whether those measures are sensible measures of innovation output or not, merely that under this framework, value added is the implied output measure.

Third, an important issue for measurement is that if this framework is accepted, then we need immediately to face up to the fact that most innovation is not in value added as currently measured. This is set out in more detail below, the but key point is that (1) we are not saying here that we are seeking to measure how innovation has impacted on a given amount of output, but that it has also changed output and (2) we will need to measure the knowledge stock and its share of payments in total costs.

To see this point, we replace the model above with one where we assume that the intangible sector produces knowledge that is an intermediate input into the other sectors. Thus we have

(a) Intangible sector: $N_{t}=F^{N}\left(L_{N, t}, K_{N, t}, t\right) ; \quad P_{t}^{N} N_{t}=P_{t}^{L} L_{N, t}+P_{t}^{K} K_{N, t}$

(b) Tangible sector: $I_{t}=F^{I}\left(L_{I, t}, K_{I, t}, N_{I, t}, t\right) ; \quad P_{t}^{I} I_{t}=P_{t}^{L} L_{I, t}+P_{t}^{K} K_{I, t}+P_{t}^{R} N_{I, t}$

(c) Consumption sector: $C_{t}=F^{C}\left(L_{C, t}, K_{C, t}, N_{C, t}, t\right) ; \quad P_{t}^{C} C_{t}=P_{t}^{L} L_{C, t}+P_{t}^{K} K_{C, t}+P_{t}^{R} N_{C, t}$

Which replaces the flow of new intangibles produced in the intangible sector as intermediate inputs to the other sectors, rather then the knowledge stock as an input to the other sectors. In this case, 
nominal GDP and the growth rate of real GDP are defined without the output of intangible capital since it is treated as an intermediate

$$
\begin{aligned}
P^{Q^{\prime}} Q^{\prime} & =P^{C} C+P^{I} I \\
\Delta \ln Q^{\prime} & =\frac{P^{C} C}{P^{\prime Q} Q^{\prime}} \Delta \ln C+\frac{P^{I} I}{P^{\prime Q} Q^{\prime}} \Delta \ln I
\end{aligned}
$$

Where a prime on $\mathrm{Q}$ denotes that we are considering the case where intangibles are expensed. We assume the same concerning inputs $\mathrm{K}$ and $\mathrm{L}$ and similar manipulations give the sources of measured value added growth as the following

$$
\Delta \ln Q^{\prime}=s^{\prime K} \Delta \ln K+s^{\prime L} \Delta \ln L+\Delta \ln T F P
$$

Where

$$
s^{\prime X}=\left(P^{X} X / P^{\prime Q} Q^{\prime}\right), \quad X=K, L, R
$$

From which we can see that the innovation index here would be only $\triangle \ln T F P$. This differs from (8) in that (a) output is different (b) $\Delta \ln T F P$ is different because the factor shares are evaluated at different amounts and (c) the intangible index is less explained since we are not accounting for investments building the knowledge stock.

Finally, in measuring output we face the formidable difficulty of measuring public sector and service sector output. For reviews of measurement of public sector output, see the ONS productivity handbook (2007) and for service sector, see Haskel (2007). Due to data problems discussed therein, we do not deal with the public sector in the data below and we regard our data for financial and business services as tentative.

\subsubsection{Input measures: tangible capital}

As pointed out by e.g. Jorgenson and Grilliches (1967) the conceptually correct measure of capital in this productivity context is the flow of capital services. This raises a number of measurement problems set out, for example, in the OECD productivity handbook (2004).

\subsubsection{Input measures: labour}

Our labour input measure is composition-adjusted labour input. The following points are worth noting. First, any labour improvement due to firm-specific training is in the intangible measures. One might ask if there is double counting with the labour quality measures, but the implicit assumption is 
that if firms are willing to pay for training it will be firm-specific and so they reap the returns of higher productivity rather then the returns internalising into wages. Second, since households are not counted as firms, they cannot do any investment and hence their acquisition of human capital is not counted. Since much of this is public sector, this suggests that we might ascribe increases in labour quality as, in part due to the public sector, but of course the mix of labour might change due to e.g. immigration or flows from/to the unemployment register, which is of course not entirely due to public sector education provision. Third, one might argue that labour quality improvement is part of innovation since it reflects building knowledge capital in the labour force. We see no reason to exclude it and so the data on labour composition is presented below.

\subsubsection{Input measures: intangible capital and $\triangle \ln T F P$}

To measure the growth of intangible/knowledge capital at the firm, one has to make some assumptions about how firms acquire knowledge. There would appear to be at least three sources. First, firms might get it for free: observing what other firms do for example. Second, the firm might invest its resources in-house. Finally, firms might buy in knowledge from the outside.

At least two issues arise: (a) in practice, how are we to measure these sources? and (b) in theory, is using existing knowledge (e.g. obtained for free) an addition to the overall knowledge stock? Regarding (a) the following points are worth noting. First, free knowledge will be part of $\Delta \operatorname{lnTFP}$. However, $\Delta$ lnTFP also includes other effects such as mismeasurement, the impact of non-constant returns and imperfect competition etc. Second, in-house spending will be missed if one only looks at output of the creative industries, although such output should help understand bought-in innovation.

The question of whether these three sources of knowledge constitute increases in the overall knowledge stock is difficult. Presumably in-house spending would do so; if it is performed in house, it suggests that firms either cannot find knowledge elsewhere. The other sources are more complicated.

The crucial question for our purposes is whether any spending on ideas (a) creates a new idea and (b) creates an asset. If spending on buying ideas that are used up in the production process can be identified, the conceptual answer is to treat them as intermediate consumption. For example, spending by a cinema to buy a film to project for example is expressly treated as intermediate consumption (which has the convenient property of raising only the knowledge stock at the filmmaker).

Another example where ideas are rented is a licence e.g. to use a production technology. Spending on such licences are typically excluded from R\&D in the official numbers; so for example, spending on a technology licence is only counted as $R \& D$ if the knowledge from such a licence is a 
key part of the ongoing R\&D process in the firm ${ }^{4}$. Although such licences are excluded from R\&D spending, there may be a problem if they are included in other spending numbers. One issue here is software, where OECD rules mandate that spending on software licences is counted as investment in intangible assets, despite the view that such spending is merely double counting the (discounted) value of the investment by Microsoft in the knowledge asset. The rationale for its inclusion is that such software is often not capitalised by the software writer originally anyway and that the licence to use the software is generally for a period of time, which then follows the convention that leasing assets for a long period e.g. aircraft is treated as renting of capital by the lessor. One conservative view might then be to treat own-account spending on software as innovation spending in case purchased spending includes such licence payments and double counting.

Although there is not a licence, there may be other spending categories where existing ideas are bought in; purchased management consulting for example. Presumably firms are buying knowledge from consultants, who, since they already have the knowledge, may constitute an addition to the firm's knowledge stock, but does not constitute an addition to the overall knowledge stock. There are number of points here. First, the market test implicit in our definition answers those who argue that management consultants have no useful knowledge to impart. Second, it is not clear that such knowledge is the duplication of ideas held at the management consultancy, for it may be that the service being sold is the application of such ideas to provide new ideas at the firm. Attempting to measure whether an idea is fundamentally new or not is beyond the purview of this paper and so we shall again fall back on the market test to rule on this question. Rather then debate on whether it is truly new idea we use the market test, if a firm bought it, it must have some value in expectation to the firm as an idea, and if it raised output then the firm must have commercialised it successfully.

Third, it is of course quite likely that spending on ideas, even if they are exactly the same as those existing outside the firm is an input into business change within the firm. So upgrading from software version $\mathrm{X}$ to version $\mathrm{Y}$ would seem like an example where it is only the idea itself that is bought in. But if it is a necessary part of upgrading knowledge in the business as a whole then new ideas are involved. Untangling what fraction of purchases are genuinely new and what are existing is very hard. So this again suggests two ways in which one might proceed. A conservative approach would be to regard own-account spending as generating new ideas and purchased spending as wholly of existing ideas. Another approach would be to allow the admission of all spending.

In sum, some payments for ideas that are used up in production (e.g. licences to show movies or use a production process) we shall exclude and count as intermediate consumption. Other payments for ideas we shall generally treat as adding to overall knowledge stocks, whilst acknowledging that there may be some double counting of ideas production.

\footnotetext{
${ }^{4}$ The ONS Business Enterprise R\&D survey says "Exclude such activities as: Royalties payments for the use of the results of research and development unless required as an essential part of the research and development programme within the unit.
} 
Finally, we need then to convert spending on knowledge into increases in the knowledge stock and the impact on output. We do this by assuming a certain fraction of spending to be investment, a depreciation rate and a price for knowledge, the latter being essentially the GDP deflator. All these assumptions are discussed in Corrado, Hulten and Sichel (CHS, 2004), Giorgio Marrano, Haskel and Wallis (GHW, 2007). These are clearly all areas where more research on establishing these parameter is needed: for the moment, we note that GHW test the robustness of the model to changes in e.g. the fraction of innovation spending we think it investment, or depreciation. In addition Appendix 3 sets out a rough indication of where we think further research is necessary to better understand the gaps in our knowledge, focussing on knowledge capital building in financial services and organisations.

\section{Relation to other work}

There are (at least) four broad areas of related work. First, are the various definitions of innovation that have been postulated. Second, is the TFP work. Third, there is other work that discusses, for example, the distinction between innovation, invention, adoption etc, and fourth the work on creative industries and hidden innovation. The latter two are discussed in the working paper.

\subsection{Relation to innovation definitions}

\subsubsection{Frascati Manual (2002)}

The Frascati Manual (2002) definition is perhaps the natural starting point since it is the definition from the R\&D data. It is as follows (Para 1.5.3)

Technological innovation activities are all of the scientific, technological, organisational, financial and commercial steps, including investments in new knowledge, which actually, or are intended to, lead to the implementation of technologically new or improved products and processes.

The main feature of this definition is the stress on activities, which may be thought of in our context as inputs to the knowledge stock. The outputs are not expressly set out. In particular the verb "implementation" is somewhat broad. It fits with the idea of using marketed output but could also be non-marketed. Note that the emphasis here is on technological rather then organizational: the latter is taken up by the Oslo manual.

\subsubsection{Oslo manual def of innovation}

24. A technological product innovation is the implementation/commercialisation of a product with improved performance characteristics such as to deliver objectively new or improved services to the consumer. A technological process innovation is the implementation/adoption of new or significantly improved production or delivery methods. It may involve changes in equipment, human resources, working methods or a combination of these. 
The first part of this definition uses the notion to "deliver objectively new or improved". There is no definition of "objectively", but our use of the market would be one (but by no means all: one might have, for example, industry experts coming to a view on significant innovations as in the SPRU data). Note that the definition of inputs is wide and includes organisational innovation.

\subsection{3 "Innovation metrics" definition}

The definition adopted by the Gutierrez group is as follows.

The design, invention, development and/or implementation of new or altered products, services, processes, systems, organizational structures, or business models for the purpose of creating new value for customers and financial returns for the firm.

This definition fits with ours closely. First, it concentrates in the final part of the sentence on commercialised products (as they point out, it is orientated at a private sector definition) and so is in line with our proposed measure that effectively focuses on market tested innovation. Second it is broader in its inclusion of new products and services than just scientific and technological ideas, includes organizational ideas too. It does not however, as we do, explicitly exclude new value that arises due to the application of existing capital and labour and ideas but since it does mention new extensively.

\subsubsection{NESTA (2008)}

NESTA offer the following definition:

Change associated with the creation and adoption of ideas that are new-to-world, new-tonation/region, new-to-industry or new-to-firm.

This definition suffers from the problem of being rather vague in talking about "change”, it not being clear whether this is more output as a result of innovation or input of both. It is helpful in pointing out that an innovation to firm A can be something that another firm has already implemented, but this can lead to some problems as set out above.

\subsubsection{Other definitions}

Barber (2008) reviews a number of definitions. First he points out the DTI (Department of Trade and Industry, now split into two separate departments) definition namely the 'exploitation of new ideas' which focuses on new knowledge, but it not clear on how to measure exploitation. Second, he reviews 
Nelson's definition (), "the processes by which firms master product designs and production processes that are new to them, if not to the world, nation or sector" which is not clear on how to measure mastering. Third, he suggests "Innovation is the process by which firms and other organisations master new product designs, production processes and business methods and commercially exploit them or bring them into use. New means new to the firm or organisation, if not to the world, nation or sector" which fits well with the Gutierrez definition and explicitly stresses both the "mastering" of a new design or processes and its commercialisation .

\subsection{Relation to TFP, ICT and intangibles literature}

Regarding TFP, our index is firmly in the Jorgensonian tradition and indeed the motivation builds directly on an example suggested by Jorgenson (2007) in his evidence to the Gutierrez committee, see above quote footnote 1 .

As for ICT, much of the recent economics work focusing on ICT can be thought of as very much trying to improve our understanding of capital deepening and innovation. Regarding hardware, improved deflators, quality adjustment and the development of industry data are part of the attempt to build better measures of the tangible capital stock and understand and measure better the TFP changes in the economy (e.g. how TFP in the semi-conductor sector translates into higher LPG and $\triangle \ln T F P$ in the whole economy). Regarding software, the incorporation of software as an asset is again part of the process to recognize spending on intangibles as building a (knowledge) capital stock. Both these developments are commented on in the Oslo manual (see e.g. para 55) without an explicit reference to innovation. See, for example, Jorgenson, Ho and Stiroh (2007) for work.

Finally, this work is clearly related to recent work on intangibles and growth. Beginning with the Oslo manual, it discusses measuring intangible investment as another way of examining the ways by which firms improve prod and performance. They define first investment as spending expected to give a return over more than a year. On categories, they say "There is no standard definition, but it is generally taken to cover expenditure on non-routine marketing, training, software and some other similar items, in addition to current expenditure on R\&D. It covers current expenditure on TPP innovation but also comprises elements which are not part of TPP current innovation expenditure (for example it includes all of the firm's training and marketing expenditure in general, not simply training or marketing in connection with the introduction of technologically new products and processes). It does not cover tangible investment such as capital TPP innovation expenditure, which includes capital expenditure on R\&D, acquisition of new machinery and equipment related to TPP innovations.” So all of this is again consistent with our headings and discussion. 
Two explicit papers on the relation of the intangible spending research programme to innovation are van Ark and Hulten (20007) and Corrado (2007). Van Ark and Hulten (2007) discuss the relation between intangibles investment and innovation. As they point out, current statistical practice often does not measure innovation well: on the input side, R\&D measurement is somewhat crude and not broad and on the output side, intangible spending is not capitalised and new products sometimes not well measured. They point out that with an expanded view of capital following the CHS argument innovation "...would appear in several forms in the sources of growth framework: through the explicit breakout of IT capital formation, through the addition of intangible capital to both the input and output sides of the source of growth equation, through the inclusion of human capital formation in the form of changes in labor "quality," and through the "multifactor productivity" (MFP) residual, which includes the effects of technological externalities and spontaneous improvements in organization and technology of production (although this cannot be separated from other factors in the residual, like measurement error)." So this then is consistent with our framework. Later in their paper they identify innovation with knowledge capital, as we do in this paper, but they have a slightly different defintion"The restated sources of growth analysis in CHS (2006) contains another message. The combined importance of intangibles, IT capital, and labor quality (which largely reflects human capital) explains nearly 60 percent of productivity growth. This reflects the importance of 'knowledge capital' - our measure of innovation - as a driver of growth (p.11" We are defining here innovation as knowledge capital, but to exclude IT capital, this being part of the physical capital stock.

Finally, Corrado, summarising the CHS work argues that the CHS focus was a macro level measure founded on innovation and further states "The average businessperson knows that innovation is a complex, gradual process, and that it often involves many firms making incremental investments in a range of activities over many years.” Mokyr (2005) calls these micro inventions, as distinct from larger scale inventions that change process and market organisations. We do not distinguish in this paper between such innovations (or indeed continuous and discontinuous innovations) but rather measure them in terms of their output impact per input (which might of course be higher with some types of inventions), see also Baumol (2003) and Mokyr (2002).

\section{Results $^{5}$}

\subsection{Section summary}

This section sets out results for different industries. Thus we make a number of contributions. First, we set out spending data on intangibles for each sector. Second, we set out the results for growth accounting including intangible investment in each industry. This is of interest beyond the innovation 
index but can also be used to give an innovation index for the sectors. Finally, we show how the industries combine to produce overall data which will attempt to understand how each sector has contributed to overall innovation.

\subsection{Industry data sources}

\subsubsection{Intangible definitions and sources}

We set out the results for each industry's spending on intangible assets. Table 1 sets out our industry definitions, which exclude the public sector. Note that real output measures in group 6 are likely poorly measured.

Table 2 sets out our intangible investment categories. They are by now standard and the interested reader is referred to GHW for a discussion. A number of issues are worth summarising here. First, measurement of own-account spending will potentially be important. As discussed above, this is important so that the contribution of knowledge spending is not just restricted to the creative industries. Second, the list of intangible assets is that set out by CHS and may not be exhaustive. More research is clearly necessary on this question. Third, the translation from spending to investment requires an assumption about what fraction of measured spending creates an enduring asset. The assumptions here follow CHS and are set out in column 4, clearly more data is needed here. Fourth, as the table sets out one needs to make assumptions about depreciation/deterioration rates, see column 5. Whilst more data is clearly needed in this area, our work in GHW suggested that some of the key findings were robust to changes in these assumptions. Fifth, price deflators are assumed, see column 6, and remain an untested work area.

Our industry-level data are availed from 1997 to 2005. They start in 1997 because IO tables are available from this time and IO tables end in 2005.

\subsubsection{Output, capital and labour}

The data source for output, capital and labour is the UK component of the EUKLEMS Growth and Productivity Accounts, which covers the period 1970-2005. However, 1997-2005 is the period for which industry-level data on intangibles are available and so we focus on this period. This database includes measures of output, and various categories of employment and capital at the industry level. Data are presented for 71 industries, classified according to the European NACE revision 1 classification. We then have carried out the aggregation needed to collapse these data according to the six industries described in Table 1. Note that EUKLEMS provide growth accounting data, but since we have expanded the amount of capital and changed value added we have to modify these results.

From the output and intermediate accounts of the EUKLEMS dataset we have used the series of industry gross output and gross value added at current basic prices, intermediate inputs at current

\footnotetext{
${ }^{5}$ These results use the findings in Mariela dal Borgo’s MSc Econmics thesis at the University of Warwick.
} 
purchasers' prices and their correspondent price and volume indices. Intermediate inputs comprise energy, materials and services.

To measure labour services we needed the series on labour compensation and total hours worked by person engaged, which include hours worked by self-employed and family workers. Labour compensation reflects total labour costs and also includes both labour compensation of employees and of self-employed. Note that, as labour compensation of self-employed is not registered in the National Accounts, the EUKLEMS data are based on an assumption that the compensation per hour of self-employed is equal to the compensation per hours of employees.

To obtain the composition of labour component, we need the more detailed labour input tables, where the shares of various labour types in total compensation or total hours are given. In particular, the breakdown is provided for 18 types of labour, resulting from the following categories: educational attainment (high, medium and low skill), gender (male and female) and age (15 to 29, 30 to 49 and 50 and over).

The tangible capital variables from EUKLEMS that we used are nominal and real gross fixed capital formation, the corresponding price index, real fixed capital stock and capital compensation, all disaggregated by type of assets. Capital compensation equals the sum of the gross operating surplus, which includes mixed income, plus taxes on production, after subtracting compensation of employees. In practice, it is derived as value added minus labour compensation. We shall of course amend capital compensation to incorporate compensation for intangible capital assets.

Real series are given at 1995 prices. EUKLEMS distinguishes nine type of assets, of which we are going to take data for only five, four categories from Machinery and Equipment (Transport equipment, Computing and Communications Equipment and Other Machinery and Equipment) and Total Non-Residential Investment). As we have our own estimates for software, we are not going to use the data from EUKLEMS, except for the price index. We excluded residential structures because they should not be considered for productivity-measurement purposes.

Depreciation rates for ICT tangible capital are the same as in the EUKLEMS database, which in turn follows Jorgenson et al. (2005). Like for intangible assets, they are assumed to be the same for all industries and were set to 0.315 for Computing Equipment and in 0.115 for Communication Equipment. For the other tangible assets that we are considering here we also used EUKLEMS rates that are based on the BEA. Note that these rates vary over industries but not over time and, when it was necessary (industries 1, 2, 5 and 6), we took the average of all the rates that correspond to each industry of our classification.

In theory, taxes should be included to account for differences in tax treatment of the different asset types and different legal forms. However, given that the EUKLEMS database does not provide data on capital tax rates by country, industry and year and that Timmer et al. (2007) point out that evidence for major European countries shows that their inclusion has only a very minor effect on growth rates of capital services and TFP, we did not introduced the tax adjustment. 


\subsection{Industry intangible spending results}

Here we use data from 2000 to 2004 (our investment data starts in 1997 and so we think that data before 2000 is too dependent on starting values).

Table 3 reports the levels of investment, both in tangible and intangible assets, for the six industries and the whole market sector for the period 1997-2005. The Financial sector emerges as one of the more important investors in intangibles, with outlays of $£ 45 \mathrm{bn}$ in the last year. Note too intangible investment in manufacturing is $2 \frac{1}{2}$ times that of tangible investment. Overall, tangible investment is smaller than intangible investment.

Figure 1 shows the fraction of all intangible investment in 2000 and 2004 accounted for by each intangible asset type. In both years, investment in firm-specific human capital was the most important in terms of its share in total intangible investment (above 20\%). If we consider together the purchased and own-account components of design, then it occupies the second place being near 18\% in both years. Looking at the three broader classes, investment in economic competencies was the more significant in both years, with a share representing approximately half of total intangible investment (50\% in 2000 and 54\% in 2004). Innovative property represented around a third of total investment (34\% in 2000 and 32\% in 2004) and it more than doubles the share of the only ICT component of intangibles (software), which declined from $16 \%$ in 2000 to $14 \%$ in the last year. Therefore, comparing year 2000 with year 2004, there seems to be a reallocation of expenses in intangibles towards categories that create economic competencies (with the exception of advertising) against those related with innovative property and computerized information (except for own-account architectural and engineering design).

Figure 2 shows the series of total investment in intangibles categories, for the period 19972005. Note that most of the intangible categories either follow an increasing trend over time or stay flat, with the exception of Copyright, Licenses and Mineral exploration that declined during this eightyear period. The growing categories between 1997 and 2005 are categories from economic competencies: Market Research (but still the spending there is relatively low), Organizational Structure and Training. In terms of absolute levels, Training (£28bn), Organizational Structure (£20.6bn) and Software (£17.4bn) concentrated most to investment in 2005.

To get a sense of the data by industry, Figure 2 shows the ratios of total investment in all intangible categories to industry value added plus intangible investment. This shows that manufacturing and financial and business services are the most investment intensive.

Figure 3 shows the data by category. Training, Design and Software are the most important categories. Lastly, Figure 4 shows data by category and industry. The financial sector emerges as one of the more important investors in intangibles, having invested near $£ 45 \mathrm{bn}$ in the last year. Figure 3 
shows that it lead the investment levels in five categories (Software, Purchased design, Advertising, Market Research and Organizational Structure), and also was one of the fastest growing over the period with an expansion of 79\%. It is followed by Manufacturing industry, which invested $£ 31.4 \mathrm{bn}$ in 2005, and Trade, Hotels and Transport with $£ 31.2 \mathrm{bn}$. In the case of Manufacturing, the bulk of the investment was concentrated in R\&D, Own-account Design and Organizational Structure, but overall it grew by 20\% from 1997 to 2005). Investment in Trade, Hotels and Transport experienced a large expansion over this period, particularly for own-account design and categories from Economic Competencies. The remaining industries, i.e. Agriculture, Electricity, Gas and Water and Construction, invested a total of $£ 9.7 \mathrm{bn}$ in 2005 , which represents a growth of $42 \%$ in comparison with 1997 . Only outlays in the agricultural sector have fallen over this period, due to a decline in most categories of intangibles. The conclusion that emerges from these figures is that service sectors is investing more in intangibles than goods producing sectors. In 2005, Finance and Trade, Hotels and Transport invested 86\% more than the other four industries, which represents a difference of £35bn.

\subsection{Industry growth accounting results}

\subsubsection{Theory}

We follow Jorgenson et al. (2007) in relating industry data on TFP growth to aggregate level data from value added. If we assume that due to competition each capital asset type and worker type is paid the same across industries then we have the following industry and aggregate variables for each type where industry is defined as industry $j$ and the aggregate variables are unsubscripted:

$$
\begin{aligned}
& \Delta \ln K=\sum_{k} \bar{w}_{k} \Delta \ln K_{k} \text {, capital type } k \\
& \Delta \ln L=\sum_{l} \bar{w}_{l} \Delta \ln L_{l} \text {, labour type l } \\
& \bar{w}_{k}=P_{K, k} K_{k} / \sum_{k}\left(P_{K, k} K_{k}\right), \bar{w}_{l}=P_{l, l} K_{l} / \sum_{l} P_{L, l} K_{l}, K_{j}=\sum_{j} K_{k, j} \forall k, L_{j}=\sum_{j} L_{l, j} \forall l, \\
& \bar{w}_{t}=0.5\left(w_{t}+w_{t-1}\right)
\end{aligned}
$$

The definition of real aggregate value added depends on the assumptions one makes about value added at the industry level. If all factors are paid the same, a value added function exists at the industry level which is the same across industries and capital and labour are paid the same, then aggregate real value added is simply the sum of industry real value added. If we relax these assumptions and assume a PPF at the industry level then aggregate real value added is 


$$
\Delta \ln V \equiv \sum_{j} \bar{w}_{j} \Delta \ln V_{j}, \quad w_{j}=P_{V, j} V_{j} / \sum_{j}\left(P_{V, j} V_{j}\right), \bar{w}_{j}=0.5\left(w_{j, t}+w_{j, t-1}\right)
$$

For each the industry level, we have the following gross output defined $\Delta \ln T F P$

$$
\Delta \ln T F P_{j}=\Delta \ln Y_{j}-\bar{v}_{K, j} \Delta \ln K_{j}-\bar{v}_{L, j} \Delta \ln L_{j}-\bar{v}_{X, j} \Delta \ln X_{j}
$$

where industry gross output is defined as

$$
\Delta \ln Y_{j}=\bar{v}_{V, j} \Delta \ln V_{j}+\bar{v}_{X, j} \Delta \ln X_{j}
$$

Finally, we have the definition of econ wide $\triangle \ln T F P$

$$
\Delta \ln T F P \equiv \Delta \ln V-\bar{v}_{K} \Delta \ln K-\bar{v}_{L} \Delta \ln L
$$

We are now in a position to write down the industry contributions to aggregate value added, which consists of capital input, labour input and TFP

$$
\begin{aligned}
\Delta \ln V \equiv \sum_{j} \bar{w}_{j} \Delta \ln V_{j} \\
=\left(\sum_{j} \bar{w}_{j} \frac{\bar{v}_{K, j}}{\bar{v}_{V, j}} \Delta \ln K_{j}\right) \\
+\left(\sum_{j} \bar{w}_{j} \frac{\bar{v}_{L, j}}{\bar{v}_{V, j}} \Delta \ln L_{j}\right) \\
+\sum_{j} \frac{\bar{w}_{j}}{\bar{v}_{V, j}} \Delta \ln T F P_{j}
\end{aligned}
$$

with each industry's contribution to the aggregate growth in V, K and L and TFP i.e. the terms in (18) being

$$
\begin{aligned}
& C T_{-} V_{j}=\bar{w}_{j} \Delta \ln V_{j} \\
& C T_{-} K_{j}=\bar{w}_{j} \frac{\bar{v}_{K, j}}{\bar{v}_{V, j}} \Delta \ln K_{j} \\
& C T_{-} L_{j}=\bar{w}_{j} \frac{\bar{v}_{L, j}}{\bar{V}_{V, j}} \Delta \ln L_{j} \\
& C T_{-} T F P_{j}=\frac{\bar{w}_{j}}{\bar{v}_{V, j}} \Delta \ln T F P_{j}
\end{aligned}
$$


where the prefix CT defines the contributions of each component and summing each CT term gives the aggregate contribution. Thus the tables below do the following. First, we set out the gross output growth accounting results for each industry. Second, we take these data and set out the contributions for each industry to the growth of aggregate value added. Third, we sum up the contributions across industries to the decomposition of aggregate (market sector) value-added. For in each case we carry out the decomposition with and without intangibles.

\subsubsection{Results for whole market sector}

Let us start by considering the results for the whole market sector. These are set out in Table 4. They use the direct aggregation across industries approach. The growth rates are in the top panel and the contributions to labour productivity growth (LPG) are in the bottom. Note that the row corresponding to hours worked differ between each column because they are weighted by the share of industry valueadded. The columns entitled without software are data which excludes all intangibles including software; that entitle with intangibles includes all intangibles with software. Overall value-added growth per hours worked is positive under both settings and equals 2.74 p.p. for the period 2000-2005 (this is just a coincidence because value-added might change when intangibles are accounted for).

Note that the final column, relative to the without software column, shows much more capital deepening and less $\triangle \ln T F P$. Indeed, the contribution of $\triangle \ln T F P$ is almost zero in the final column. So on this measure, what would our innovation index say? One way of expressing it is that the innovation index (intangible capital deepening plus $\Delta \ln T F P$ ) grew $1.19+0.05=1.24 \%$ pa, 2000-2005, which is $45 \%$ of overall LPG $((1.24+0.45) / 2.74)$ (61\% if one includes labour quality). Note that if one calculates this from the column excluding intangibles, one obtains $\Delta \ln T F P$ as $1.07 / 2.74=40 \%$ of LPG, suggesting that ignoring knowledge capital building, under these assumptions, understates the role of innovation over this period.

In sum, the innovation index presented here suggests that innovation accounted for $45 \%$ of market sector growth in GDP per person, 2000-2004.

\subsubsection{Results by industry}

What was the industry contribution to this overall figure? The results for the sources of growth of labour productivity (LPG), described in equation (18), are displayed in Table 5 for the period 20002005. This shows in the first two columns the growth rates of gross output and of hours worked, the difference between the two being LPG in column 3.

The top panel corresponds to the base case in which we exclude software and all other intangibles from published data, whereas the bottom panel corresponds to the case including all intangibles. In the fourth column we show total capital deepening contribution to LPG (defined as the product of the value share of capital and the growth rate of capital services per hour worked), 
decomposed, in the next columns, into the ICT tangible and non-ICT tangible components and also the intangible component in the bottom panel. Next, we present labour quality contribution (the product of the value share of labour and the growth rate of labour services per hour worked), intermediate input deepening (the product of the share of intermediate input and its growth rate per hour worked) and TFP growth, which contributes to LPG one-for-one. Note that the differences in gross output and LPG growth between the top and the bottom panel are mainly due to errors of approximation in the building of the real growth series. Hence, we can take the values from the first three columns, as well as those corresponding to labour quality contribution, as the same with or without intangibles, just as our analysis of the previous section suggests.

The following points emerge from the Table. First, the high performing LPG sectors were "Manufacturing” and "Trade, Hotels and Transport", with an expansion of $3.79 \%$ pa and $3.03 \%$ pa respectively, followed by Construction (2.10\% pa.) and Finance (1.69 \% pa.). Agriculture and Electricity, Gas and Water slowed down.

Second, what are the accounting contributions to these changes? We can see that in the base case (excluding software and other intangibles, top panel), the main sources of growth are intermediate input deepening (especially in Manufacturing, Construction and Trade). Without intangibles, see lower panel, total capital deepening never exceeds $0.67 \%$ pa (with the exception of agriculture). By contrast, with all intangibles, total capital deepening is never below $0.68 \%$ pa. So total capital deepening rises and $\triangle \ln T F P$ falls with the addition of intangibles.

The source of this rise in overall capital deepening is of course intangible capital deepening. The effect of intangible capital deepening, relative to tangible capital deepening is smallest in Agriculture and Electricity, and highest in Manufacturing. Trade and Financial services have seen about equal intangible capital deepening and tangible capital deepening, but note the importance of ICT tangible capital deepening in Financial Intermediation in particular.

Further details on capital deepening are set out in Table 6. This shows the capital deepening term per hour worked for each type of capital decomposed into its share (column 1, capital weight), its growth rate (column 2, capital growth) and its total contribution (column 3, capital deepening), so each row describes the $\Delta \ln K_{j}$ terms in (13) with the third column being $\Delta \ln K_{j}$ for the $\mathrm{j}=1 . .6$ industries. We can see there that the shares of intangible assets in total capital are larger than the shares of ICT but still lower than the shares of the other tangible assets. In turn, their growth rates are much faster than the growth rates of the latter and very close to the high rates of ICT assets. Not surprisingly, this combination of high shares and soaring growth rates implies that the investment in intangibles accounts for a sizeable fraction of economic growth and productivity, even higher than the one derived from ICT use.

What of TFP? Returning to Table 5, it shows that TFP, before the incorporation of intangibles, did not play a prominent role among the sources of output growth and moreover, in the case of Agriculture, its contribution was negative. With the addition of intangibles, we cannot predict 
a priori how it is going to change. What our estimates reveal is that there was a large decline in TFP growth in the six industries. The consequence of this was that in other three industries -Electricity, Gas and Water, Construction and Finance- TFP growth became negative. Finally, if we rank our set of industries according to TFP growth, we find that Manufacturing and Trade, Hotels and Transport are at the top of the list, meanwhile Electricity, Gas and Water and Agriculture have the lower rates of TFP growth in the market sector. This picture emerges either with or without intangibles and also if we use for the ranking the alternative measure of productivity, LPG.

Since we have seen that capital deepening is a major contribution to LPG, we can ask what industries are contributing most to overall capital deepening? For example, we have seen fast intangible capital deepening in manufacturing, but if manufacturing is a small weight in the overall economy, does it have an impact? Table 7 answers this question. The sum of the contributions in the bottom line of the panel equals the figure in Table 4 (so these terms decompose the capital and labour contributions in equation 19). For capital, we include the industry contribution for total capital and for the sub-components, ICT tangible, non-ICT tangible and in the bottom panel also for intangible capital. In the case of total capital we also report the industry share (column 1) and the growth rate of total capital input per hours worked (column 2). For labour input we also presented first the industry share (column 7), then the growth rate of labour quality (column 8) and finally the product of these two terms that defines the industry contribution to aggregate labour quality. We also included in the last two columns, for comparative purposes, the sum of the weights of capital and labour input (which equals the value-added weights displayed in the first column of Table 7) and the industry employment level as a share of total employment. Table 7, bottom panel shows two interesting findings. First, regarding ICT tangible capital deepening, the leading sector contributions are Trade, and Financial and Business Services. Second, regarding intangible capital deepening, the leading sector contributions are Manufacturing, Trade and Financial. Indeed, manufacturing has contributed $0.54 / 1.19=45 \%$ of intangible capital deepening despite being $15 \%$ of employment.

Finally, Table 8 reports the contribution of each industry to aggregate value-added and TFP growth for the period 2000-2005 (so these are the value added and TFP terms in (19)). Notice that the figures for the whole market sector are obtained as the sum of each row and the contributions are the same as the ones reported before in Table 6. For value-added, we showed in the first column the average share of industry value-added in the aggregate, in the second column the growth rate and in the last one the product of these two terms, which measures the industry contribution to aggregate value-added per hours worked. For TFP growth, we included the Domar-weight, the industry TFP growth and the product of these terms that is the industry contribution to aggregate TFP. Note that the Domar-weights sum to 2.35 and 2.02 in the top and bottom panel respectively, which are values higher than 1.

This table reveals that LPG growth for the whole market sector is mostly accounted for by Manufacturing, Trade, Hotels and Restaurants and Finance, whereas the other industries make a very 
small contribution or even a negative one (like Agriculture). But even when aggregate LPG growth is the same (2.74\%pa) with or without capitalizing intangibles, note that the contribution of each industry differs somewhat. Indeed, Finance becomes less important vis-à-vis Manufacturing and Trade, Hotels and Restaurants when intangibles are accounted for. Regarding TFP contribution, it falls after adding intangibles, determined mainly by the slowdown in the TFP of Manufacturing and Finance (which actually become negative) and to a lesser extent, of Trade, Hotels and Restaurants. In conclusion, to understand the productivity performance -both LPG and TFP- of the whole market sector, we need to track the evolution of those industries with the largest value-added and Domar weights (Manufacturing, Trade, Hotels and Restaurants and Finance).

\subsubsection{Relation to innovation}

Table 9 presents the innovation index. Each column shows the intangible capital deepening term and $\triangle \operatorname{lnTFP}$ and their sum and the bottom panel expresses all this as a sum of LPG of $2.74 \%$ pa. We see the following. First, the overall intangible capital deepening term and $\triangle \ln T F P$ terms account for about $45 \%$ of total LPG. Second, the most important contributors to overall intangible capital deepening are manufacturing, followed by trade and financial services. These sectors account for 58\%, 38\% and $14 \%$ of intangible capital deepening. Finally, if one were to include labour quality, from Table 7, lower right panel, one would add $0.45 \%$ pa to these figures, making the innovation index contribution $61 \%$ (=(1.24+0.45)/2.74)of labour productivity growth over the period, with manufacturing, trade and financial services contributing $0.16 \%$ pa, $0.13 \%$ pa and $0.14 \%$ pa to the labour quality growth of $0.45 \%$ pa.

\section{Conclusion}

In this paper we have tried to

(a) propose an implementable innovation index,

(b) relate it to existing innovation definitions and

(c) show whole-economy and industry-specific results for the UK market sector, 2000-2005.

Our innovation measure starts by observing that we could get more GDP without innovation by simply duplicating existing physical capital and labour (e.g. adding a second aircraft and crew on an existing route). Thus we propose to measure innovation as the additional GDP over and above the addition existing physical capital and labour. In our measure this is the contribution to GDP growth of market sector investment in knowledge/intangible capital. This contribution is measured by spending on knowledge/intangible assets and TFP growth. We have related our measure to the literature on innovation definitions, TFP, creative industries and hidden innovation. We have argued that it captures many of the intentions in the various innovation definitions, whilst focussing on innovation as 
opposed to invention. Our measure in very much in line with the growth accounting approach in Economics and, by adopting conventions to measure own-account spending our data incorporates work on the creative industries and the hidden innovation point that innovation takes place outside such industries.

We implement our measure for six UK market sector industries, 2000-2005, combining with output and tangible investment data from EUKLEMS. Our main findings are as follows. Over 20002005, labour productivity grew at $2.74 \%$ pa, of which the contribution of market sector knowledge capital was $1.24 \%$ pa. In turn, manufacturing accounted for about $60 \%$ of this latter figure. If one includes increase in labour skill deepening $(0.45 \% \mathrm{pa})$ as innovation, then innovation contributed $61 \%$ $(=(1.24+0.45) / 2.74)$ of labour productivity growth over the period.

We believe that the next step in this work is to run an expanded R\&D survey to obtain better data on intangible spending and service lives of knowledge assets. In recent months, we have carried out some pilot work on this and believe the results indicate that firms can answer these types of questions. These better data will be crucial to a better implementation of the framework here. 


\section{Appendix: Details of measurement of each asset category}

Following, CHS (2006) and Giorgio Marrano and Haskel (2006) we can distinguish three main classes of intangible assets: i) computerized information; ii) innovative property and iii) economic competencies. The first comprises software and databases, the second mainly scientific and nonscientific R\&D, and the last one firm investment in reputation, human and organizational capital. Our primary source to build these assets are figures on intangible spending at industry level, available for the period 1997-2005 in many categories, and for 1997-2004 in others. In those cases, we opted to repeat the observation from 2004 in 2005.

The methodology and sources used to get the data on intangible expenditure by industry are described in the Report for the UK Department for Business, Enterprise and Regulatory Reform (BERR) (2008), carried out by Gil and Haskel (2008). Most of the sources and methods used there follow CHS (2006) and GHW, which conduct their estimates for the total private sector. But some changes were needed to estimate the series at industry level.

According to this Report, the original sources used to compile aggregate data provide an industry breakdown that not always is related to a standard classification like the SIC. This is because some of the sources are not official ONS data or have been collected for other purposes that do not require a SIC classification. In consequence, based on the available data, they combine the SIC codes at the lowest possible level of aggregation and this gives six main sectors that are described in Table 1 . In that Table we also included the correspondences with the NACE industry classification because it is followed by the EU KLEMS Growth and Productivity Accounts that we will use for output, tangible capital and labour. Note that the categories described in Table 1 exclude activities mostly outside the market sector like Public administration (L), Education (M), Health (N), Personal services (O), Private households (P) and Extra-territorial organizations (Q).

Table 2 summarizes the categories of intangible assets that we are going to consider in this work, the primary data sources used to measure expenditure in intangibles, the proportion of spending considered as investment and the depreciation rates allocated to each asset.

The third column of the table shows the fraction of current spending that might be considered investment based mainly on the assumptions of CHS (2006). The idea of their study is first to estimate expenditures on each type of intangibles and then, based on economic research and evidence, it determines how much of each category of expenditure might be considered business investment depending on whether it could yield future consumption. We used these conversions factors to obtain our estimates of intangible assets.

The last column reflects the depreciation rates for each type of asset based also on CHS (2006) assumptions. They point out that relatively little is known about depreciation rates for intangibles. In consequence, due to the limited information available, they have to assume constant rates, which imply a geometric depreciation pattern. Moreover, both conversion factors and depreciation rates are assumed to be the same for all industries.

Finally notice that as there are no deflators available for intangible assets, we assumed that they are all equal to the value added deflator. The approach of using a price measure rather than a wage measure as a proxy for the price of intangibles is also advocated by CHS (2006), until specific deflators for intangibles can be estimated. This assumption can introduce a bias in the estimates of the VICS, but the direction of the bias is not clear. If intangible prices grow less than value added prices, then we may be underestimating the overall growth of capital services.

In the following paragraphs we are going to expand the information summarized in Table 2 based on the Report for the BERR, Gill and Haskel (2008).

Computerized information

Computerized information comprises computer software, both purchased and own-account, and computerized databases. The main source for computer software investment is contained in the ONS work described by Chesson and Chamberlin (2006). The estimates of purchased software are based on company investment surveys. And for own-account software, they use the earnings of employees in 
computer software occupations . Note that to avoid double counting additional spending on computerised databases is not considered as it is already included in the ONS software estimates. The third column from Table 2 shows that the 100 percent of software spending should be considered as investment. The depreciation rate appearing in the last column is estimated in 33 percent, which is the BEA's assumption for own-account software.

\section{Innovative property}

For Scientific R\&D performed by business in the UK, expenditure data are derived from the Business Enterprise R\&D survey (BERD). This survey intends to capture R\&D aimed at solving scientific and technological problems and, therefore, it includes explicitly items such as design and market research. To avoid double counting of R\&D and software investment, R\&D spending in "computer and related activities" (SIC 72) was subtracted from the R\&D spending of the financial sector (industry 6). Also, in order to derive an actual measure of the UK R\&D expenditure, it was necessary to subtract R\&D exports (included in BERD data) and to add R\&D imports (excluded from BERD), by sector. International trade data on R\&D is taken from the ONS. Table 2 also shows that the proportion of Scientific R\&D expenditure that goes to investment is 100 percent. The depreciation rate assumed is 20 percent, in the middle of the range of the rates reported in the existing literature on $R \& D$, according to CHS (2006). With the exception of new architectural and engineering design, these assumptions are used also for the rest of the categories that comprise innovative property.

Mineral exploration and Copyright and license costs are already capitalized in the National Accounts. Mineral exploration includes the cost of drilling and related activities such as surveys. As it is only undertaken by the mining sector (included in industry 1) a breakdown by industry is not provided. In the case of copyright and license costs, only the publishing of artistic originals can be accounted as part of the market sector because the rest corresponds to recreational and cultural activities (SIC 92), which is not part of our definition of market sector. In this case there is also no industry breakdown because all publishing is imputed to manufacturing. Hence, estimates for these two intangibles are the same as those presented in GHW.

The estimates of New products development costs in the financial industry are also the same as in GHW and they are all carried out by the financial sector. Thus, there is no industry breakdown in this case either. Following CHS (2006), expenditure is calculated as the 20 percent of total intermediate consumption by the financial services industry, after subtracting the purchase of other intangibles that are already counted elsewhere. Data are taken from the Use Table.

As regards New architectural and engineering design, the industry data are obtained using a different methodology than CHS (2006) and GHW, given that purchased and own-account designs are estimated separately. The purchased component is estimated from the IO Tables using data on "Architectural activities and technical consultancies". Turnover data from ABI are used to subtract part of this aggregate that cannot be considered an investment asset . Own account output is estimated using data on the design industry output and on the wage bill of designers working inside and outside the design sector, which were taken from the Annual Survey of Hours and Earnings (ASHE). Note that in this case we rely on our own assumptions for the conversion factors, setting investment as the $50 \%$ of total spending, due to these methodological changes.

$\mathrm{R} \& \mathrm{D}$ in social sciences and humanities is estimated as twice the turnover of R\&D in "Social sciences and humanities" (SIC 73.2), where the double is assumed to capture own-account spending as in GHM. Turnover data are taken from ABI.

Advertising expenditure is estimated from the IO Tables by summing intermediate consumption in Advertising (product group 113) across all industries. It is remarked in the Report that these figures are not capturing the own-account component that should be computed, but in contrast, they do include the classified advertising (i.e. small advertising at the end of newspapers, typically for sale or vacancies), which is unlikely to be asset building. In addition, CHS (2006), based on the existing literature on advertising, estimate that only about 60 percent of total advertising expenditures can be considered investment, i.e., have effects that last more than one year. Note that together with market 
research this category presents the main deviations from unity among the conversion factors in the third column. They also conclude that advertising had a service life of less than 3 years, with a depreciation rate of 60 percent per year, as the last column shows.

Market research by industry is estimated with data on market research and management consultancy (product group 111) from the Use Table and the IO Table. ABI data on value-added are used to extract the market research component from the aggregate of product group 111. Final figures are doubled to consider the own account market research. Assumptions on the fraction of expenditure that is capitalized and on depreciation rates are the same as for advertising.

The Firm-specific human capital expenditure is estimated as the costs of employer-provided worker training. Our data were estimated using the National Employer Skills Survey (NESS2004), which collects data on employer expenditure on on-the-job and off-the-job training. As the split by sector is provided for 2004 only, an industry-level time series is built by backcasting 2004 figures with the EU KLEMS wage bill time series. Also, it was introduced an adjustment to consider all UK because the NESS covers just England. CHS (2006) assumed that all training expenditure is capitalized and estimated the depreciation rate in 40 percent, averaging the rates for advertising and $\mathrm{R} \& \mathrm{D}$. This is because training combines a long-lasting dimension similar to $R \& D$ and a short-lived dimension similar to advertising. The first is derived from the link between employer-provided training and firm-level productivity and the second from the fact that investment through strategic planning, adaptation and reorganization reflects the constant need of the business to adapt to changing economic conditions.

Organizational structure reflects management time to enhance the productivity of the firm. It has a purchased component, represented by management consultant fees, and an own-account component, represented by the value of the executive time spent on improving the effectiveness of business organizations. The first is estimated as the revenues of the management consulting industry, using a survey conducted by the UK Management Consulting Association (MCA). The industry breakdown is provided for 2005 only, thus, the time series are constructed following a backcasting procedure similar to the one used for Firm-specific human capital. Also, it is necessary to add management consultancy imports to consider the consulting services purchased from abroad. As regards own-account expenditure, it is estimated as 20 percent of the managers' earnings, following CHS (2006) assumption that 20 percent of their time is spent on organization building activities. Data on earnings are taken from ASHE. The third column indicates that 80 percent of the purchased organizational structure and all the own-account are capitalized. In this study we use the total sum of the two components, and therefore, we take the average of the conversion factors that is 90 percent. The depreciation rates are the same as for investment in training, 40 percent. 


\section{References}

Aghion, Philippe \& Howitt, Peter, 2005. "Growth with Quality-Improving Innovations: An Integrated Framework," Handbook of Economic Growth, in: Philippe Aghion \& Steven Durlauf (ed.), Handbook of Economic Growth, edition 1, volume 1, chapter 2, pages 67-110 Elsevier.

Aghion, P and Howitt, P., (2008), , Capital, innovation, and growth accounting”, Oxford Review of Economic Policy 2007 23(1):79-93

Carol Corrado (2007), “Comment submitted to the Advisory Committee on Measuring Innovation in the 21st Century Economy”, http://www.innovationmetrics.gov/comments/051107FederalReserveBoard.pdf

Clayton, T., Dal Borgo, M., and Haskel, J., (2008), “An Innovation Index Based on Knowledge Capital Investment: Definition and Results for the UK Market Sector”, Report for NESTA, http://www.coinvest.org.uk/bin/view/CoInvest/CoinvestInnovIndex

Corrado, C. A., Hulten, C. R. and Sichel, D. E. (2005). Measuring Capital and Technology: An Expanded Framework. In Measuring Capital in the New Economy, Vol. 65 (Eds, Corrado, C. A., Haltiwanger, J. C. and Sichel, D. E.). Chicago: The University of Chicago Press.

Corrado, C. A., Hulten, C. R. and Sichel, D. E. (2006). Intangible Capital and Economic Growth. NBER Working Papers 11948, National Bureau of Economic Research, Inc.

Denison, E. F. (1962). The sources of economic growth in the United States and the alternatives before us. Committee for Economic Development.

Domar, E. D. (1961). On the Measurement of Technological Change. The Economic Journal 71, 709-729.

EU KLEMS Database, March 2008, see Marcel Timmer, Mary O'Mahony \& Bart van Ark, The EU KLEMS Growth and Productivity Accounts: An Overview, University of Groningen \& University of Birmingham; downloadable at www.euklems.net

Frascati Manual (2002), Proposed Standard Practice for Surveys on Research and Experimental Development, http://europa.eu.int/estatref/info/sdds/en/rd/rd_frascati_manual_2002.pdf

Galindo Rueda, F., Haskel, J., and Pesole, A., (2008), “How much does the UK spend on Design”, working paper, www.ceriba.org.uk.

Gill, V, and Haskel, J, (2008), “ Industry-level Expenditure on Intangible Assets in the UK”, working paper, http://www.coinvest.org.uk/bin/view/Colnvest/CoinvestGilHaspaper

Jorgenson, D. W., (2007). Productivity. Cambridge, Mass.: MIT Press.

Jorgenson, D. W., Ho, M. S., Samuels, J. D. and Stiroh, K. J. (2007). Industry Origins of the American Productivity Resurgence. Economic Systems Research, Taylor and Francis Journals 19, 229-252.

Marrano, M. G., Haskel, J. and Wallis, G. (2007). What Happened to the Knowledge Economy? ICT, Intangible Investment and Britain's Productivity Record Revisited. Department of Economics, Queen Mary, University of London.

Mokyr, Joel, 2005. "Long-Term Economic Growth and the History of Technology," Handbook of Economic Growth, in: Philippe Aghion \& Steven Durlauf (ed.), Handbook of Economic Growth, edition 1, volume 1, chapter 17, pages 1113-1180 Elsevier.

OECD (2002), Oslo Manual: Guidelines for Collecting and Interpreting Innovation Data, 3rd Edition, http://www.oecd.org/document/23/0,3343,en_2649_34273_35595607_1_1_1_37417,00.html

van Ark. B., and Charles Hulten, (2007), ““'Innovation, Intangibles And Economic Growth: Towards A Comprehensive Accounting Of The Knowledge Economy” Economics Program Working Paper Series 
Table 1: Assignment of SIC codes and NACE1 sections to our 6 industries

\begin{tabular}{|c|c|c|c|c|}
\hline & Proposed sector categories & SIC code & & "NACE1 sections \\
\hline \multirow{3}{*}{1} & \multirow{3}{*}{ Agriculture, Fishing and Mining } & \multirow{3}{*}{$1-14$} & A & Agriculture, hunting and forestry \\
\hline & & & $\mathrm{B}$ & Fishing \\
\hline & & & $\mathrm{C}$ & Mining and quarrying \\
\hline 2 & Manufacturing & $15-37$ & $\mathrm{D}$ & Total manufacturing \\
\hline 3 & Electricity, Gas and Water Supply & $40-41$ & $\mathrm{E}$ & Electricity, gas and water supply \\
\hline 4 & Construction & 45 & $\mathrm{~F}$ & Construction \\
\hline 5 & $\begin{array}{l}\text { Wholesale and Retail Trade, Hotels and } \\
\text { Restaurants, } \\
\text { Communications }\end{array}$ & $50 t-64$ & $\begin{array}{c}\mathrm{G} \\
\mathrm{H} \\
\mathrm{I}\end{array}$ & $\begin{array}{l}\text { Wholesale and retail trade } \\
\text { Hotels and restaurants } \\
\text { Transport and storage } \\
\text { communication }\end{array}$ \\
\hline 6 & $\begin{array}{l}\text { Financial Intermediation and Business } \\
\text { Services }\end{array}$ & $65-74$ & $\begin{array}{c}\mathrm{J} \\
\mathrm{K}\end{array}$ & $\begin{array}{l}\text { Financial intermediation } \\
\text { Real estate, renting and business } \\
\text { activities }\end{array}$ \\
\hline
\end{tabular}


Table 2: Sources and assumptions used to build investment and capital stock in intangibles

\begin{tabular}{|c|c|c|c|c|}
\hline & Type of intangible investment & Source & $\begin{array}{l}\text { \% of spending } \\
\text { considered as } \\
\text { investment }\end{array}$ & $\begin{array}{l}\text { Depreciation } \\
\text { rate }\end{array}$ \\
\hline \multirow[b]{2}{*}{ (1) } & Computarized information & & & \\
\hline & $\begin{array}{l}\text { Computer software and computarised } \\
\text { databases }\end{array}$ & ONS estimates & 1 & 0.33 \\
\hline \multicolumn{5}{|c|}{ Innovative property } \\
\hline$(2)$ & Scientific R\&D & $\begin{array}{l}\text { Estimates based on Business Enterprise } \\
\text { R\&D survey (BERD) and ONS data }\end{array}$ & 1 & 0.2 \\
\hline (3) & Mineral exploration & National Accounts & 1 & 0.2 \\
\hline (4) & Copyright and license costs & National Accounts & 1 & 0.2 \\
\hline (5) & $\begin{array}{l}\text { New product development costs in the } \\
\text { financial industry }\end{array}$ & $\begin{array}{l}\text { Estimates based on ONS data (Use } \\
\text { Table) and CHS methodology }\end{array}$ & 1 & 0.2 \\
\hline (6) & $\begin{array}{l}\text { Purchased new architectural and engineering } \\
\text { designs }\end{array}$ & $\begin{array}{l}\text { Estimates based on IO Tables and } \\
\text { turnover data from ABI }\end{array}$ & 0.5 & 0.2 \\
\hline (7) & $\begin{array}{l}\text { Own-account new architectural and } \\
\text { engineering designs }\end{array}$ & $\begin{array}{l}\text { Estimates based on data from the } \\
\text { Annual Survey of Hours and Earnings } \\
\text { (ASHE) }\end{array}$ & 0.5 & 0.2 \\
\hline \multirow[t]{2}{*}{ (8) } & $\mathrm{R} \& \mathrm{D}$ in social sciences and humanities & $\begin{array}{l}\text { Estimates based on turnover data from } \\
\text { ABI and GHW methodology }\end{array}$ & 1 & 0.2 \\
\hline & Economic competencies & & & \\
\hline (9) & Advertising & Estimates based on IO Tables & 0.6 & 0.6 \\
\hline (10) & Market research & $\begin{array}{l}\text { Estimates based on Use and IO Tables } \\
\text { and data from ABI }\end{array}$ & 0.6 & 0.6 \\
\hline (11) & Firm-specific human capital & $\begin{array}{l}\text { Estimates based on the National } \\
\text { Employer Skills } \\
\text { (NESS2004) }\end{array}$ & 1 & 0.4 \\
\hline \multirow[t]{3}{*}{ (12) } & Organizational structure & & & \\
\hline & Purchased & $\begin{array}{l}\text { Estimates based on data from a survey } \\
\text { set up by the UK Management } \\
\text { Consulting Association (MCA) }\end{array}$ & 0.8 & 0.4 \\
\hline & Own-account & $\begin{array}{l}\text { Estimates based on data from the } \\
\text { Annual Survey of Hours and Earnings } \\
\text { (ASHE) }\end{array}$ & 1 & 0.4 \\
\hline
\end{tabular}

Notes: final two columns follow Corrado et al, 2004, assumptions. 
Table 3: Total tangible and intangible investment by industry (£bn)

\begin{tabular}{|c|c|c|c|c|c|c|c|c|c|c|c|c|c|c|}
\hline & \multicolumn{2}{|c|}{$\begin{array}{c}\text { Agriculture, Fisihing \& } \\
\text { Mining }\end{array}$} & \multicolumn{2}{|c|}{ Manufacturing } & \multicolumn{2}{|c|}{$\begin{array}{l}\text { Electricity, Gas \& } \\
\text { Water }\end{array}$} & \multicolumn{2}{|c|}{ Construction } & \multicolumn{2}{|c|}{$\begin{array}{l}\text { Trade, Hotels \& Rest., } \\
\text { Transport \& Comm. }\end{array}$} & \multicolumn{2}{|c|}{$\begin{array}{l}\text { Financial \& Business } \\
\text { Services }\end{array}$} & \multicolumn{2}{|c|}{ Total Market Sector } \\
\hline & Tangibles & Intangibles & Tangibles & Intangibles & Tangibles & Intangibles & Tangibles & Intangibles & Tangibles & Intangibles & Tangibles & Intangibles & Tangibles & Intangibles \\
\hline 1997 & 7.2 & 2.5 & 19.8 & 26.1 & 5.3 & 1.1 & 1.9 & 3.2 & 30.8 & 17.6 & 16.1 & 25.1 & 81.0 & 75.6 \\
\hline 1998 & 7.9 & 2.0 & 20.2 & 27.7 & 5.6 & 1.3 & 1.8 & 3.5 & 35.6 & 20.1 & 24.2 & 29.2 & 95.2 & 83.7 \\
\hline 1999 & 6.4 & 1.7 & 18.2 & 28.5 & 5.9 & 1.3 & 2.0 & 3.9 & 37.0 & 22.1 & 26.4 & 33.1 & 95.9 & 90.5 \\
\hline 2000 & 5.2 & 1.5 & 17.5 & 29.1 & 5.4 & 1.4 & 2.1 & 4.2 & 41.5 & 24.2 & 27.8 & 36.0 & 99.5 & 96.5 \\
\hline 2001 & 6.2 & 1.6 & 16.0 & 30.6 & 5.7 & 1.4 & 2.2 & 4.7 & 41.1 & 26.4 & 27.6 & 39.5 & 98.8 & 104.2 \\
\hline 2002 & 7.3 & 1.7 & 13.3 & 30.2 & 5.1 & 1.7 & 3.2 & 5.3 & 40.8 & 27.8 & 27.7 & 41.8 & 97.4 & 108.5 \\
\hline 2003 & 7.0 & 1.7 & 12.9 & 31.0 & 5.1 & 1.5 & 3.2 & 6.0 & 37.5 & 29.0 & 28.5 & 42.9 & 94.2 & 112.1 \\
\hline 2004 & 6.9 & 1.8 & 11.9 & 31.3 & 5.3 & 1.4 & 3.5 & 6.4 & 36.4 & 30.7 & 30.3 & 44.1 & 94.3 & 115.6 \\
\hline 2005 & 6.5 & 1.8 & 13.0 & 31.4 & 5.4 & 1.5 & 2.5 & 6.4 & 37.0 & 31.2 & 31.9 & 45.0 & 96.3 & 117.3 \\
\hline
\end{tabular}

Source: authors’ calculations. 
Figure 1: Intangible investment by type (as percentage of total)

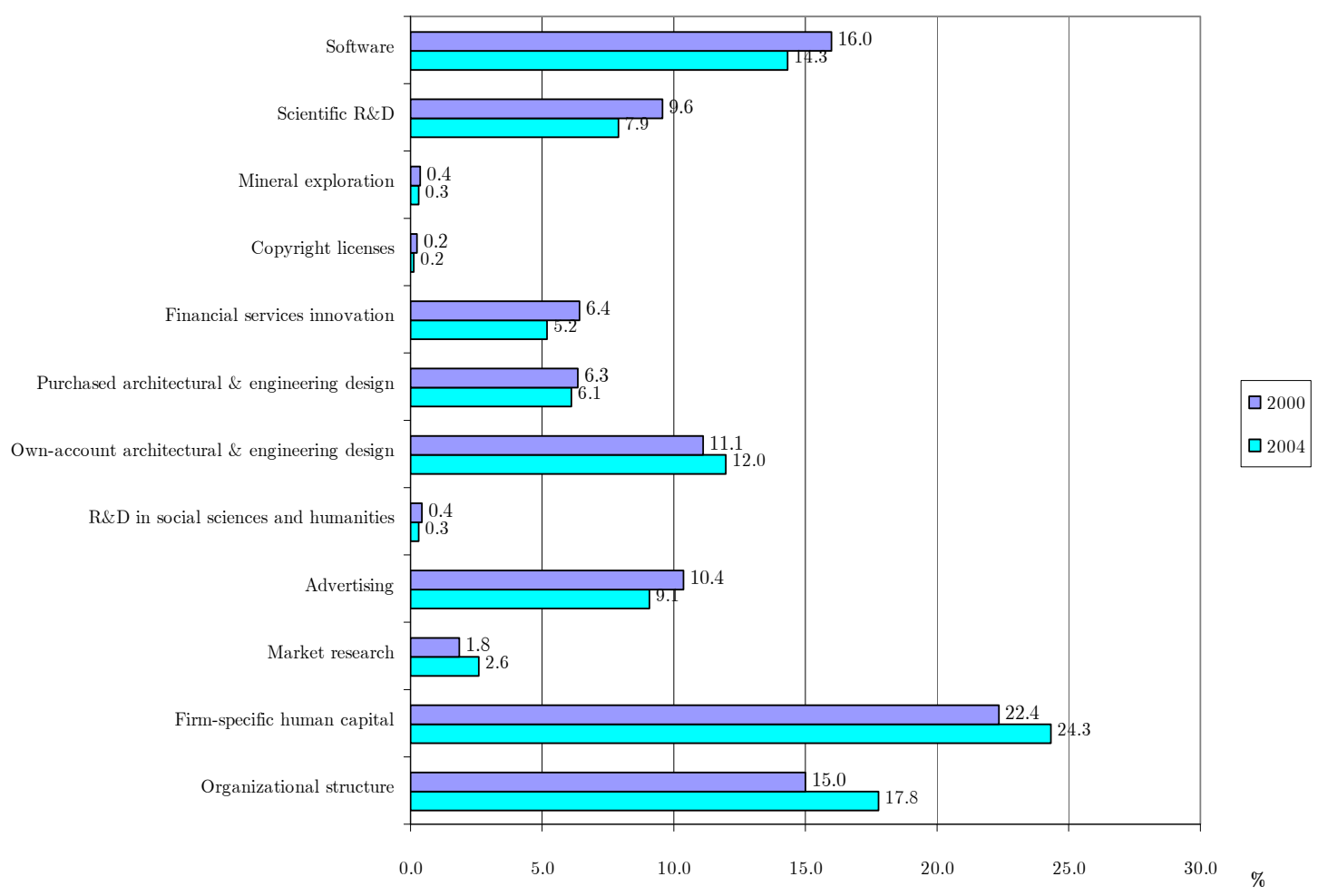

Source: authors’ calculations 
Figure 2: Total intangible investment by industry as a share of industry value-added, in percentages

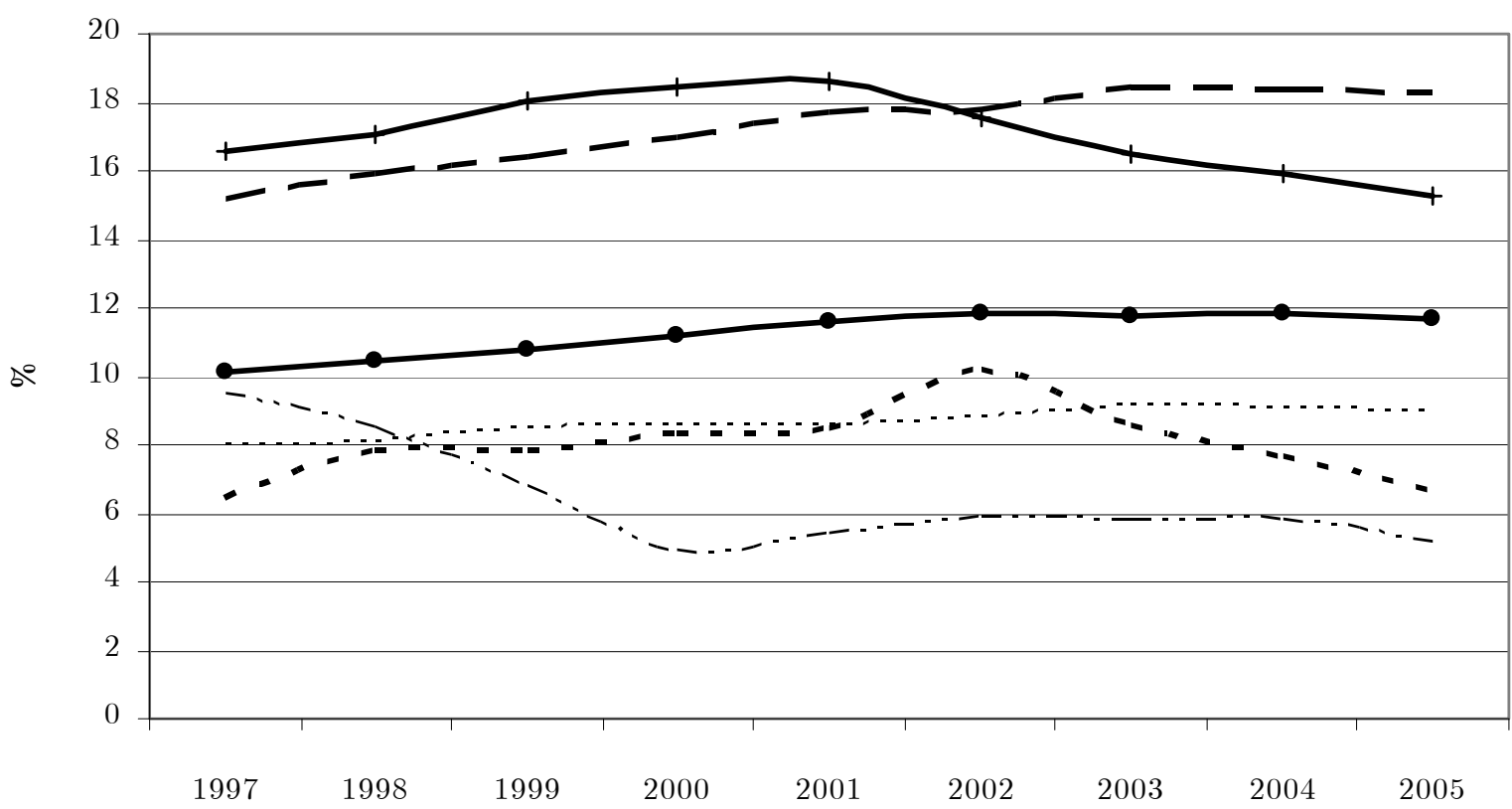

\footnotetext{
-..- Agriculture, Fishing \& Mining — - Manufacturing

- - - Electricity, Gas \& Water $\quad$....... Construction

$\longrightarrow$ Trade, Hotels \& Rest., Transp. \& Comm. — Financial \& Business Services
}

Note: industry value added is EUKLEMS value added plus intangible investment.

Source: authors' calculations 
Figure 3 Total intangible investment, by category

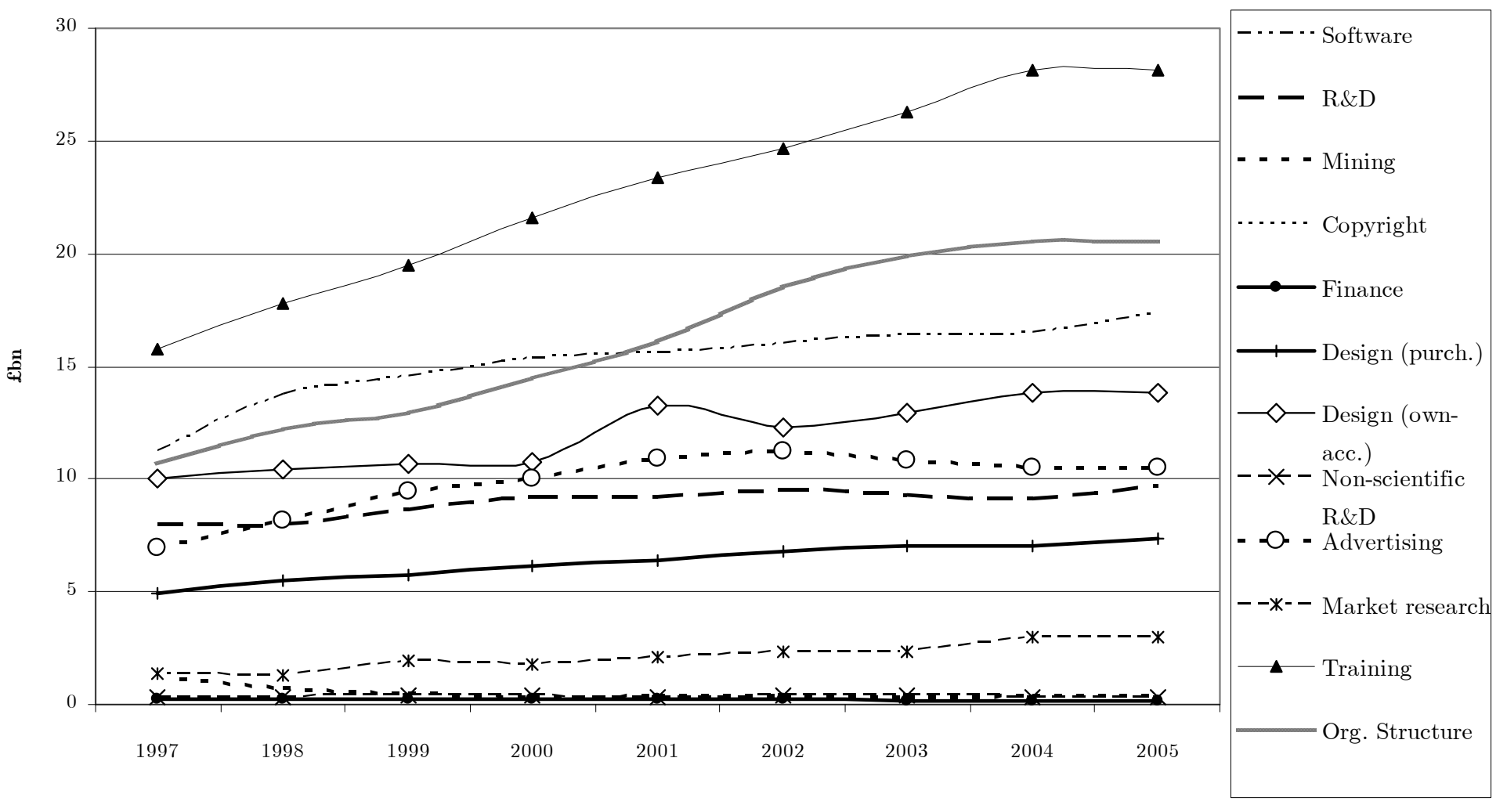


Figure 4 Total intangible investment, by industry and category

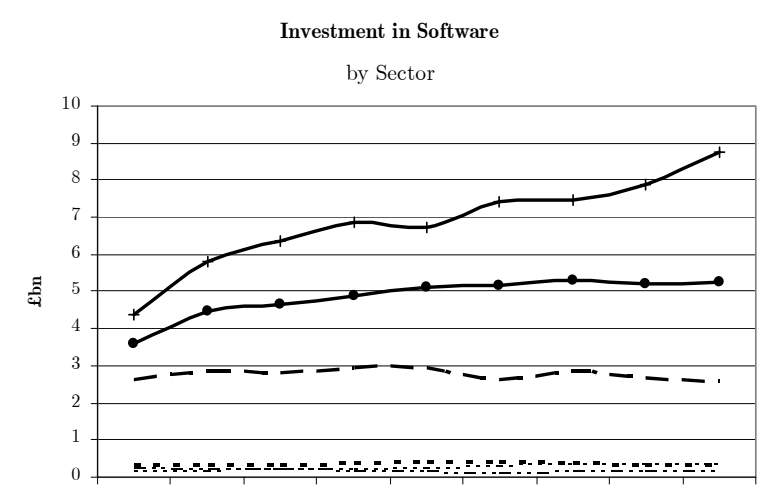

$\begin{array}{lllllllll}1997 & 1998 & 1999 & 2000 & 2001 & 2002 & 2003 & 2004 & 2005\end{array}$

Investment in Copyright licenses

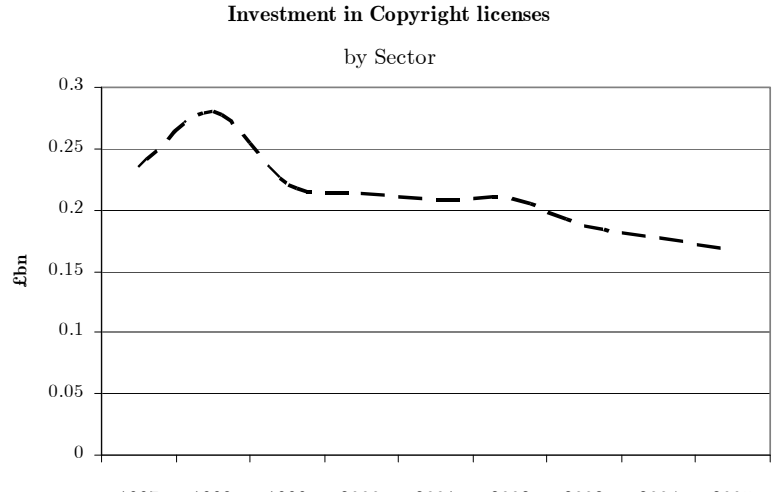

$\begin{array}{lllllllll}1997 & 1998 & 1999 & 2000 & 2001 & 2002 & 2003 & 2004 & 2005\end{array}$

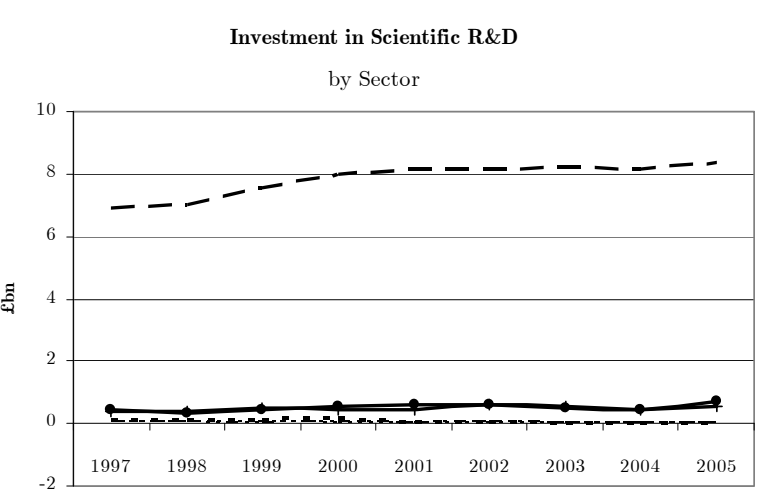

Investment in Financial services innovation

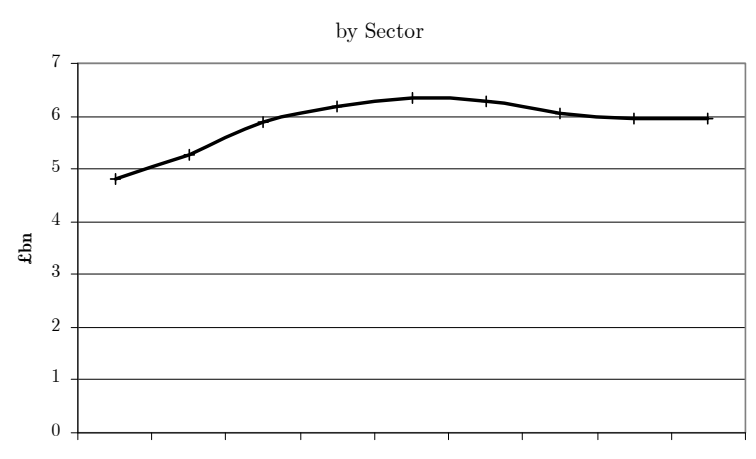

$\begin{array}{lllllllll}1997 & 1998 & 1999 & 2000 & 2001 & 2002 & 2003 & 2004 & 2005\end{array}$
Investment in Mineral exploration

by Sector

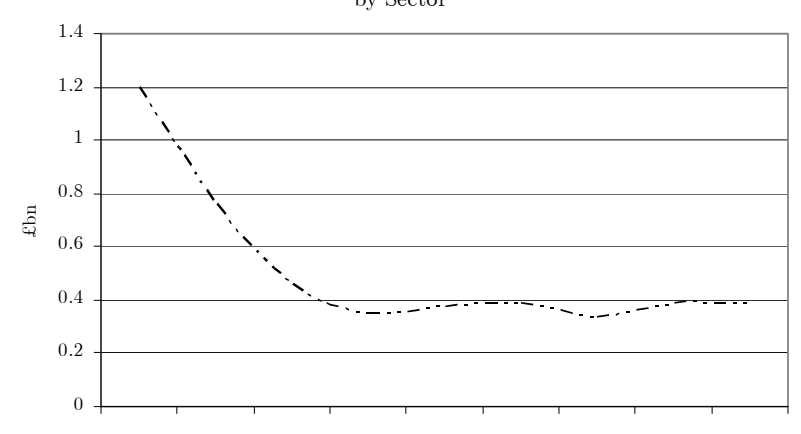

$\begin{array}{lllllllll}1997 & 1998 & 1999 & 2000 & 2001 & 2002 & 2003 & 2004 & 2005\end{array}$

Investment in Purchased architectural \& engineering design by Sector

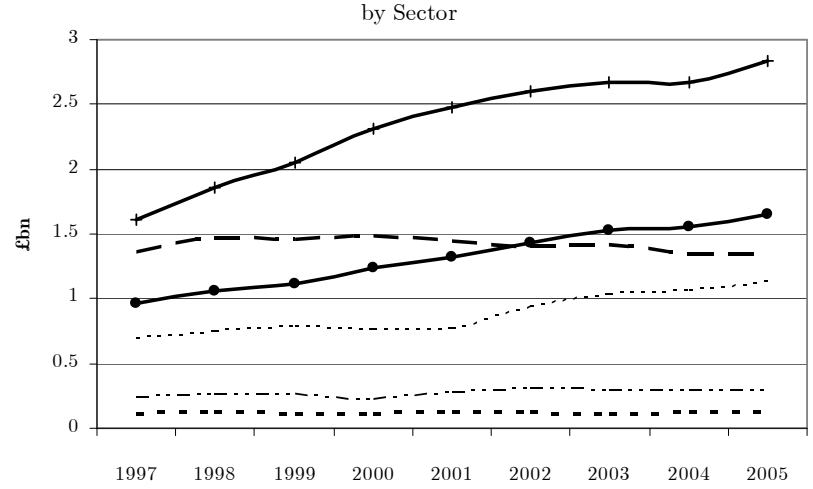

\begin{tabular}{ll}
$-\cdots-\cdot$ Agriculture, Fishing \& Mining & -- Manufacturing \\
$-\cdots-$ - Electricity, Gas \& Water & $\cdots \cdots$ Construction \\
$\longrightarrow$ - Trade, Hotels \& Rest., Transp. \& Comm. & $\longrightarrow$ Financial \& Business Services \\
\hline
\end{tabular}


FigURE 4 (cont.)

Investment in 0 wn-account architectural \& engineering design by Sector

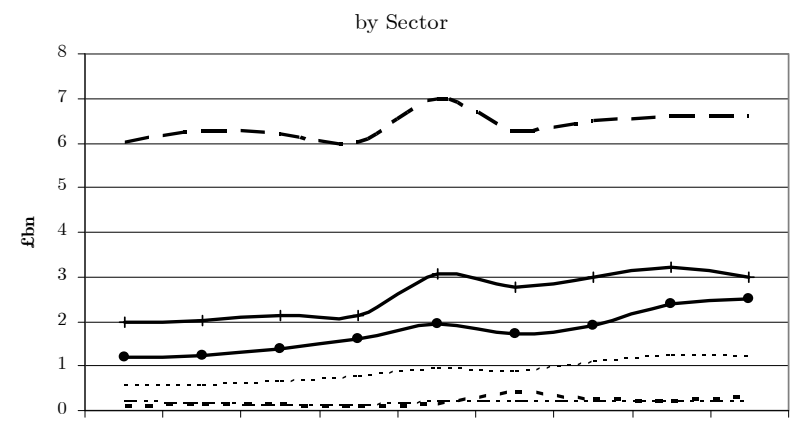

$\begin{array}{lllllllll}1997 & 1998 & 1999 & 2000 & 2001 & 2002 & 2003 & 2004 & 2005\end{array}$

Investment in Market research

by Sector

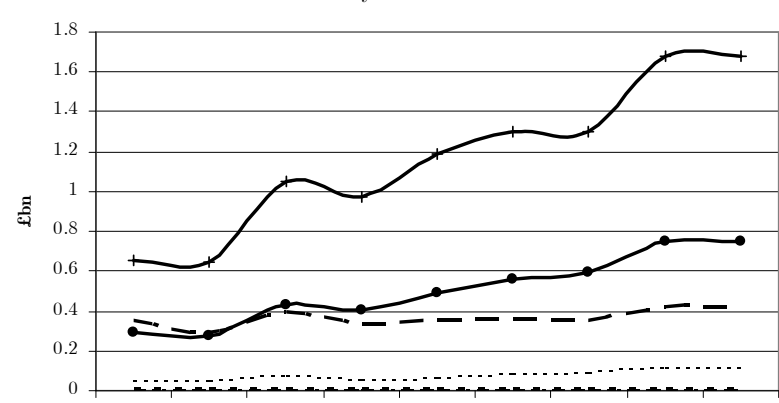

$\begin{array}{lllllllll}1997 & 1998 & 1999 & 2000 & 2001 & 2002 & 2003 & 2004 & 2005\end{array}$
Investment in R\&D in social sciences \& humanities

by Sector

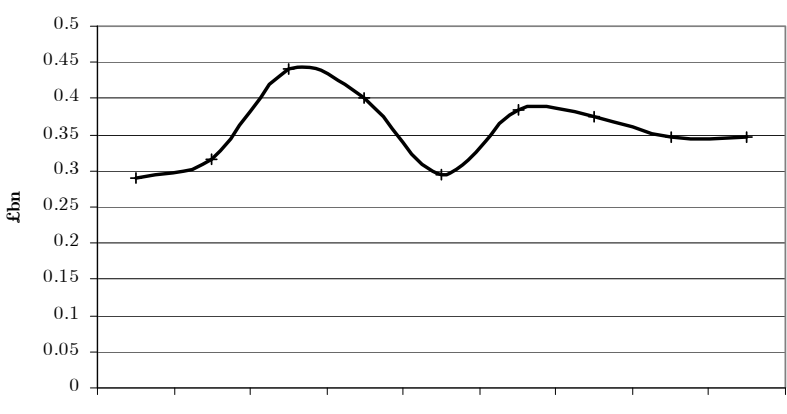

$\begin{array}{lllllllll}1997 & 1998 & 1999 & 2000 & 2001 & 2002 & 2003 & 2004 & 2005\end{array}$

Investment in Firm-specific human capital

by Sector

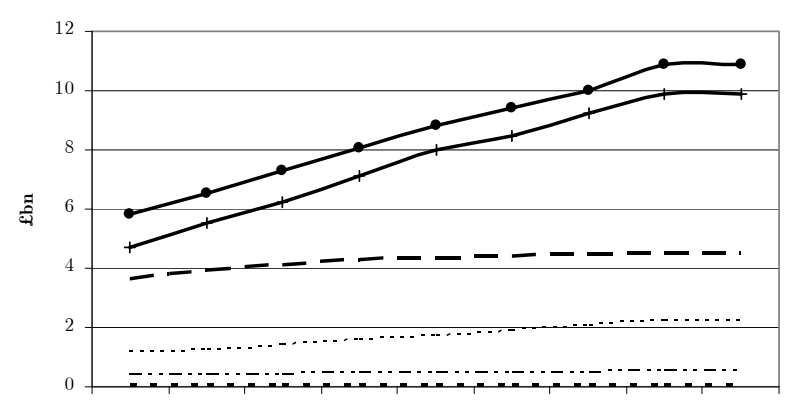

$\begin{array}{lllllllll}1997 & 1998 & 1999 & 2000 & 2001 & 2002 & 2003 & 2004 & 2005\end{array}$
Investment in Advertising

by Sector

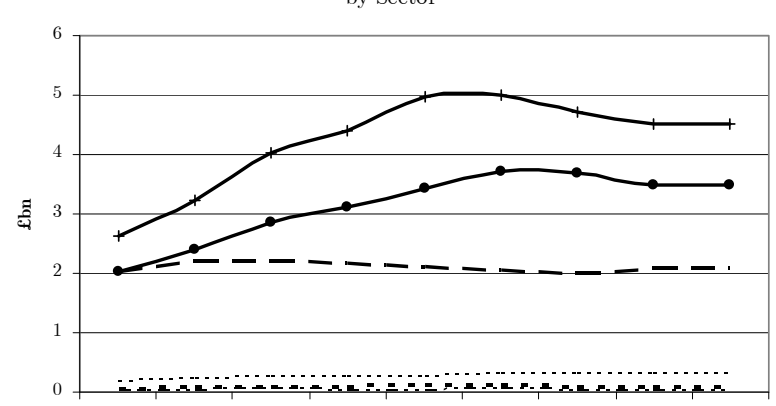

$\begin{array}{lllllllll}1997 & 1998 & 1999 & 2000 & 2001 & 2002 & 2003 & 2004 & 2005\end{array}$

nvestment in Organizational structure by Sector

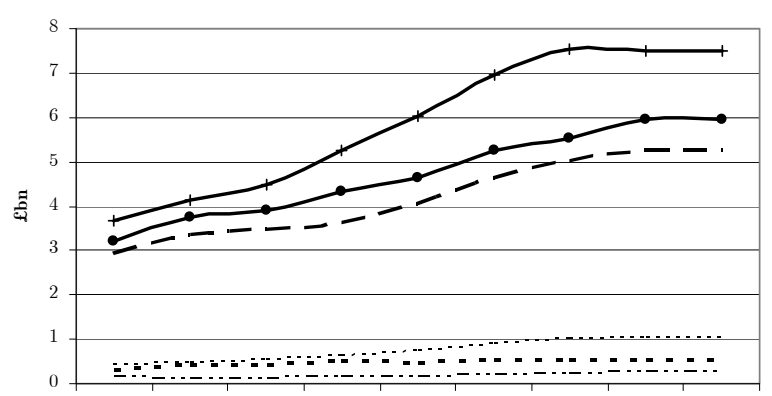

$\begin{array}{lllllllll}1997 & 1998 & 1999 & 2000 & 2001 & 2002 & 2003 & 2004 & 200\end{array}$

\begin{tabular}{|ll|}
\hline$-\cdots-\cdot$ Agriculture, Fishing \& Mining & - Manufacturing \\
$-\cdots-$ - Electricity, Gas \& Water & $\cdots \cdots$ Construction \\
$\longrightarrow$ - Trade, Hotels \& Rest., Transp. \& Comm. $\quad \longrightarrow$ - Financial \& Business Services \\
\hline
\end{tabular}


Table 4: Decomposition of aggregate labour productivity

\begin{tabular}{lcc}
\hline \hline & $\begin{array}{c}\text { Excluding } \\
\text { Software }\end{array}$ & Including All Intangibles \\
\hline & \multicolumn{2}{c}{ Growth Rates } \\
Aggregate Value-Added & 2.81 & 2.80 \\
Average labour productivity & 2.74 & 2.74 \\
Hours & 0.08 & 0.07 \\
& & Contributions \\
Average labour productivity & 2.74 & 2.74 \\
Capital Deepening & 1.15 & 2.23 \\
ICT Tangible Capital Deepening & 0.52 & 0.47 \\
$\quad$ Non-ICT Tangible Capital & 0.63 & 0.58 \\
$\quad$ Deepening & - & 1.19 \\
Intangible Capital Deepening & 0.52 & 0.45 \\
Labour Quality & 1.07 & 0.05 \\
Aggregate TFP & &
\end{tabular}

Note: All figures are average annual percentages. The contribution of an output or input is the growth rate weighted by the corresponding average share. Column entitled "excluding software" excludes software and other intangibles, other column includes all intangibles. Data in lowest panel sum to average labour productivity growth of $2.74 \%$ pa. 


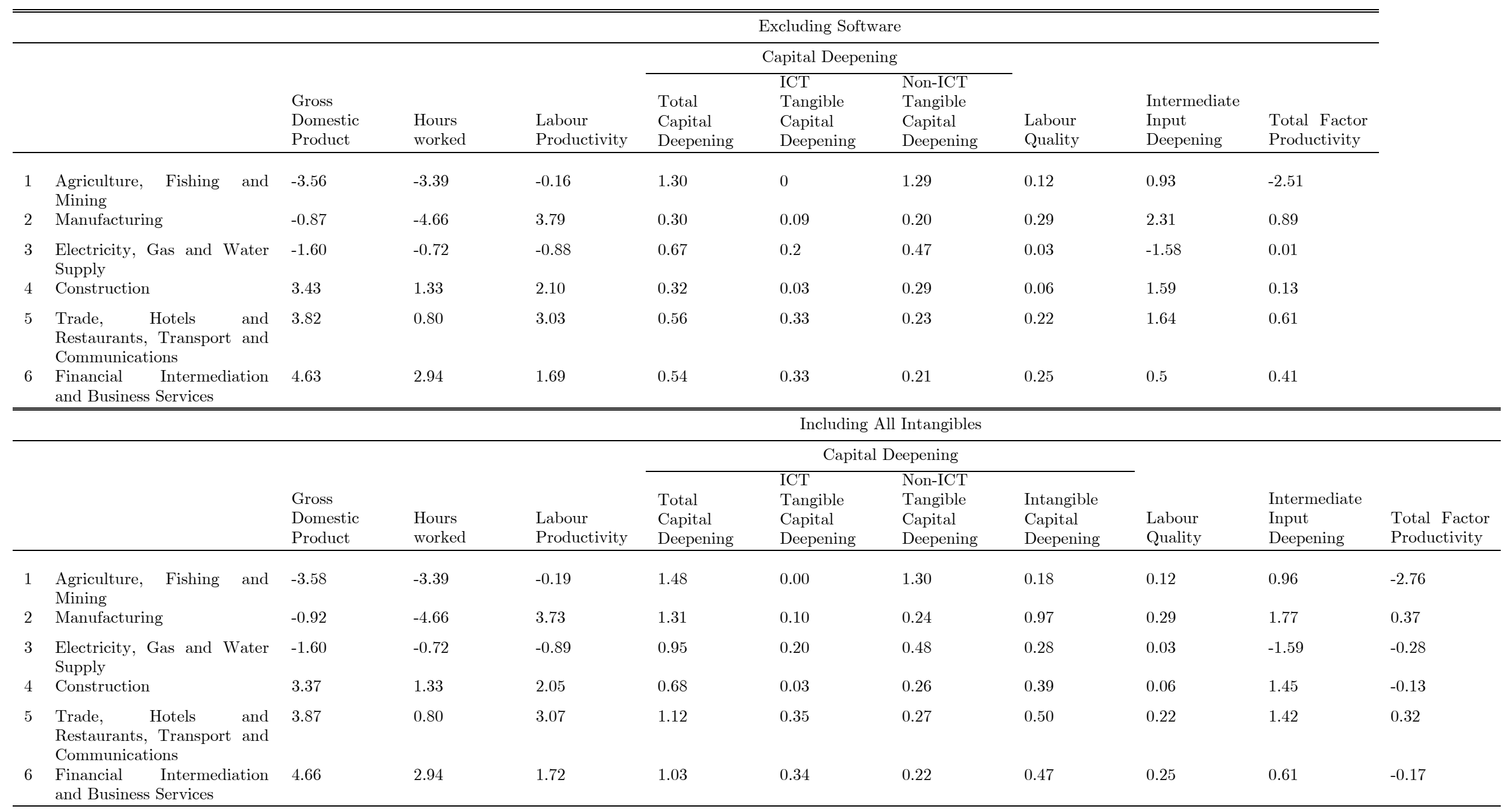

and Business Services

Note: All figures are average annual percentages. The contribution of each input is the product of its weight and the corresponding growth rate. The differences in gross domestic product and labour productivity growth between the top and the bottom panel are due to errors of approximation in the building of the real growth series. Panel entitled "excluding software" excludes software and productivity growth between the top and the bottom panel are due to errors of approximation in the building of the real growth series. Panel entited "excluding software" excludes softwate and machinery and equipment and non-residential assets. Intangible capital comprises software, scientific R\&D, mineral exploration, copyright and license costs, new product development in financial services, purchased and own-account architectural and engineering design, $R \& D$ in social sciences and humanities, advertising, market research, training and organizational structure 
Table 6: Capital weight, capital growth and capital deepening by industry and type of assets, 2000-2005

\begin{tabular}{|c|c|c|c|c|c|c|c|c|c|c|c|c|c|}
\hline & & \multicolumn{3}{|c|}{ Total Capital } & \multicolumn{3}{|c|}{ ICT Tangible Capital } & \multicolumn{3}{|c|}{ Non-ICT Tangible Capital } & \multicolumn{3}{|c|}{ Intangible Capital } \\
\hline & & $\begin{array}{l}\text { Capital } \\
\text { Weight }\end{array}$ & $\begin{array}{l}\text { Capital } \\
\text { Growth }\end{array}$ & $\begin{array}{l}\text { Capital } \\
\text { Deepening }\end{array}$ & $\begin{array}{l}\text { Capital } \\
\text { Weight }\end{array}$ & $\begin{array}{l}\text { Capital } \\
\text { Growth }\end{array}$ & $\begin{array}{l}\text { Capital } \\
\text { Deepening }\end{array}$ & $\begin{array}{l}\text { Capital } \\
\text { Weight }\end{array}$ & $\begin{array}{l}\text { Capital } \\
\text { Growth }\end{array}$ & $\begin{array}{l}\text { Capital } \\
\text { Deepening }\end{array}$ & $\begin{array}{l}\text { Capital } \\
\text { Weight }\end{array}$ & $\begin{array}{l}\text { Capital } \\
\text { Growth }\end{array}$ & $\begin{array}{l}\text { Capital } \\
\text { Deepening }\end{array}$ \\
\hline 1 & $\begin{array}{l}\text { Agriculture, Fishing } \\
\text { and Mining }\end{array}$ & 39.1 & 3.68 & 1.48 & 0.1 & 7.48 & 0.00 & 36.8 & 3.42 & 1.30 & 2.2 & 8.33 & 0.18 \\
\hline 2 & Manufacturing & 14.4 & 9.04 & 1.31 & 0.6 & 17.17 & 0.10 & 7.4 & 3.17 & 0.24 & 6.4 & 15.80 & 0.97 \\
\hline 3 & $\begin{array}{l}\text { Electricity, Gas and } \\
\text { Water Supply }\end{array}$ & 25.5 & 3.72 & 0.95 & 1.4 & 14.01 & 0.20 & 21.7 & 2.18 & 0.48 & 2.4 & 11.62 & 0.28 \\
\hline 4 & Construction & 8.2 & 8.19 & 0.68 & 0.1 & 20.94 & 0.03 & 4.0 & 6.37 & 0.26 & 4.1 & 9.97 & 0.39 \\
\hline 5 & $\begin{array}{l}\text { Trade, Hotels and } \\
\text { Restaurants, } \\
\text { Transport and } \\
\text { Communications }\end{array}$ & 17.5 & 6.32 & 1.12 & 2.6 & 12.35 & 0.35 & 10.1 & 2.63 & 0.27 & 4.8 & 10.91 & 0.50 \\
\hline 6 & $\begin{array}{l}\text { Financial } \\
\text { Intermediation and } \\
\text { Business Services }\end{array}$ & 21.7 & 4.95 & 1.03 & 1.9 & 16.67 & 0.34 & 10.6 & 2.08 & 0.22 & 9.2 & 5.75 & 0.47 \\
\hline
\end{tabular}

Note: All figures are annual averages. Capital weight is the average share of the corresponding capital payment to industry gross output (in percentage). Capital deepening is the product of the weight and the growth rate. ICT tangible capital includes computing and communications equipment. Non-ICT tangible capital includes transport, other machinery and equipment and nonresidential assets. Intangible capital comprises software, scientific R\&D, mineral exploration, copyright and license costs, new product development in financial services, purchased and own-account architectural and engineering design, R\&D in social sciences and humanities, advertising, market research, training and organizational structure. 
Table 7: Industry contributions to aggregate capital deepening and labour quality growth, 2000-2005

\begin{tabular}{|c|c|c|c|c|c|c|c|c|c|c|c|c|}
\hline & & \multicolumn{11}{|c|}{ Excluding Software } \\
\hline & & \multicolumn{5}{|c|}{ Capital Deepening } & \multicolumn{3}{|c|}{ Labour Quality } & \multirow[b]{3}{*}{$\begin{array}{l}\text { Capital } \\
\text { Labour } \\
\text { Weight }\end{array}$} & \multirow[b]{3}{*}{+} & \multirow[b]{3}{*}{$\begin{array}{l}\text { Employment } \\
\text { (\% of total } \\
\text { employment) }\end{array}$} \\
\hline & & \multicolumn{3}{|c|}{ Total Capital } & \multirow[b]{2}{*}{$\begin{array}{l}\text { Contribution } \\
\text { to Aggregate } \\
\text { ICT Tangible } \\
\text { Capital }\end{array}$} & \multirow{2}{*}{$\begin{array}{l}\text { Contribution } \\
\text { to Aggregate } \\
\text { Non-ICT } \\
\text { Tangible } \\
\text { Capital } \\
\end{array}$} & \multirow[b]{2}{*}{$\begin{array}{l}\text { Labour } \\
\text { Weight }\end{array}$} & \multirow[b]{2}{*}{$\begin{array}{l}\text { Labour } \\
\text { Quality } \\
\text { Growth }\end{array}$} & \multirow[b]{2}{*}{$\begin{array}{l}\text { Contribution } \\
\text { to Aggregate } \\
\text { Labour } \\
\text { Quality }\end{array}$} & & & \\
\hline & & $\begin{array}{l}\text { Capital } \\
\text { Weight }\end{array}$ & $\begin{array}{l}\text { Capital } \\
\text { Growth }\end{array}$ & $\begin{array}{l}\text { Contribution } \\
\text { to Aggregate } \\
\text { Capital }\end{array}$ & & & & & & & & \\
\hline 1 & $\begin{array}{l}\text { Agriculture, Fishing and } \\
\text { Mining }\end{array}$ & 0.03 & 3.42 & 0.11 & 0.00 & 0.11 & 0.02 & 0.67 & 0.01 & 0.04 & & 0.03 \\
\hline 2 & Manufacturing & 0.04 & 4.21 & 0.19 & 0.06 & 0.13 & 0.17 & 1.06 & 0.19 & 0.22 & & 0.20 \\
\hline 3 & $\begin{array}{l}\text { Electricity, Gas and } \\
\text { Water Supply }\end{array}$ & 0.02 & 2.94 & 0.05 & 0.02 & 0.04 & 0.01 & 0.27 & 0.00 & 0.02 & & 0.01 \\
\hline 4 & Construction & 0.01 & 6.82 & 0.07 & 0.01 & 0.07 & 0.07 & 0.17 & 0.01 & 0.08 & & 0.11 \\
\hline 5 & $\begin{array}{l}\text { Trade, Hotels \& Rest., } \\
\text { Transport \& Comm. }\end{array}$ & 0.08 & 4.87 & 0.38 & 0.23 & 0.15 & 0.25 & 0.60 & 0.15 & 0.32 & & 0.38 \\
\hline \multirow[t]{2}{*}{6} & $\begin{array}{l}\text { Financial Intermediation } \\
\text { and Business Services }\end{array}$ & 0.08 & 4.73 & 0.34 & 0.21 & 0.14 & 0.22 & 0.72 & 0.16 & 0.30 & & 0.28 \\
\hline & Sum & 0.26 & - & 1.15 & 0.52 & 0.63 & 0.74 & - & 0.52 & 1.00 & & 1.00 \\
\hline
\end{tabular}

\begin{tabular}{|c|c|c|c|c|c|c|c|c|c|c|c|c|}
\hline & & \multicolumn{11}{|c|}{ Including All Intangibles } \\
\hline & & \multicolumn{6}{|c|}{ Capital Deepening } & \multicolumn{3}{|c|}{ Labour Quality } & \multirow[b]{3}{*}{$\begin{array}{l}\text { Capital + } \\
\text { Labour } \\
\text { Weight }\end{array}$} & \multirow[b]{3}{*}{$\begin{array}{l}\text { Employm. } \\
\text { (\% of } \\
\text { total } \\
\text { employm.) }\end{array}$} \\
\hline & & \multicolumn{3}{|c|}{ Total Capital } & \multirow{2}{*}{$\begin{array}{l}\text { Contrib. to } \\
\text { Aggregate } \\
\text { ICT } \\
\text { Tangible } \\
\text { Capital }\end{array}$} & \multirow{2}{*}{$\begin{array}{l}\text { Contrib. to } \\
\text { Aggregate } \\
\text { Non-ICT } \\
\text { Tangible } \\
\text { Capital }\end{array}$} & \multirow{2}{*}{$\begin{array}{l}\text { Contrib. to } \\
\text { Aggregate } \\
\text { Intangible } \\
\text { Capital } \\
\end{array}$} & \multirow[b]{2}{*}{$\begin{array}{l}\text { Labour } \\
\text { Weight }\end{array}$} & \multirow[b]{2}{*}{$\begin{array}{l}\text { Labour } \\
\text { Quality } \\
\text { Growth }\end{array}$} & \multirow[b]{2}{*}{$\begin{array}{l}\text { Contrib. to } \\
\text { Aggregate } \\
\text { Labour } \\
\text { Quality }\end{array}$} & & \\
\hline & & $\begin{array}{l}\text { Capital } \\
\text { Weight }\end{array}$ & $\begin{array}{l}\text { Capital } \\
\text { Growth }\end{array}$ & $\begin{array}{l}\text { Contrib. to } \\
\text { Aggregate } \\
\text { Capital }\end{array}$ & & & & & & & & \\
\hline 1 & $\begin{array}{l}\text { Agriculture, Fishing and } \\
\text { Mining }\end{array}$ & 0.03 & 3.68 & 0.11 & 0.00 & 0.09 & 0.01 & 0.01 & 0.67 & 0.01 & 0.04 & 0.03 \\
\hline 2 & Manufacturing & 0.08 & 9.04 & 0.73 & 0.06 & 0.13 & 0.54 & 0.15 & 1.06 & 0.16 & 0.23 & 0.20 \\
\hline 3 & $\begin{array}{l}\text { Electricity, Gas and Water } \\
\text { Supply }\end{array}$ & 0.02 & 3.72 & 0.06 & 0.01 & 0.03 & 0.02 & 0.01 & 0.27 & 0.00 & 0.03 & 0.01 \\
\hline 4 & Construction & 0.02 & 8.19 & 0.13 & 0.00 & 0.05 & 0.08 & 0.06 & 0.17 & 0.01 & 0.08 & 0.11 \\
\hline 5 & $\begin{array}{l}\text { Trade, Hotels \& Rest., } \\
\text { Transport \& Comm. }\end{array}$ & 0.10 & 6.32 & 0.65 & 0.21 & 0.16 & 0.29 & 0.21 & 0.60 & 0.13 & 0.31 & 0.38 \\
\hline 6 & $\begin{array}{l}\text { Financial Intermediation } \\
\text { and Business Services }\end{array}$ & 0.12 & 4.95 & 0.55 & 0.18 & 0.12 & 0.25 & 0.19 & 0.72 & 0.14 & 0.31 & 0.28 \\
\hline & Sum & 0.37 & - & 2.23 & 0.46 & 0.58 & 1.19 & 0.63 & - & 0.45 & 1.00 & 1.01 \\
\hline
\end{tabular}


Note: All figures are annual averages. Weights depend on the industry share in aggregate value-added, the input share in gross output and the share of value-added in gross output. Contributions are the product of the weights and the input growth. Employment is the share of the industry's hours worked over total hours worked by persons engaged. Panel entitled "excluding software" excludes software and other intangibles, other panel includes software and all intangibles. 
Table 8: Industry contributions to aggregate value-added and TFP growth, 2000-2005

\begin{tabular}{|c|c|c|c|c|c|c|c|}
\hline & & \multicolumn{6}{|c|}{ Excluding Software } \\
\hline & & \multicolumn{3}{|c|}{ Value-Added per Hours Worked } & \multicolumn{3}{|c|}{ Total Factor Productivity } \\
\hline & & $\begin{array}{l}\text { Value-Added } \\
\text { Weight }\end{array}$ & $\begin{array}{l}\text { Value-Added } \\
\text { Growth }\end{array}$ & $\begin{array}{l}\text { Contribution } \\
\text { to Aggregate } \\
\text { Value-Added } \\
\end{array}$ & Domar Weight & TFP Growth & $\begin{array}{l}\text { Contribution } \\
\text { to Aggregate } \\
\text { TFP }\end{array}$ \\
\hline 1 & Agriculture, Fishing and Mining & 0.04 & -1.96 & -0.08 & 0.08 & -2.51 & -0.20 \\
\hline 2 & Manufacturing & 0.22 & 4.31 & 0.93 & 0.64 & 0.89 & 0.55 \\
\hline 3 & Electricity, Gas and Water Supply & 0.02 & 2.19 & 0.05 & 0.08 & 0.01 & 0.00 \\
\hline 4 & Construction & 0.08 & 1.35 & 0.12 & 0.23 & 0.13 & 0.03 \\
\hline 5 & $\begin{array}{l}\text { Trade, Hotels and Restaurants, Transport } \\
\text { and Communications }\end{array}$ & 0.32 & 2.90 & 0.94 & 0.68 & 0.61 & 0.41 \\
\hline 6 & $\begin{array}{l}\text { Financial Intermediation and Business } \\
\text { Services }\end{array}$ & 0.30 & 2.55 & 0.77 & 0.65 & 0.41 & 0.27 \\
\hline & Sum & 1.00 & - & 2.74 & 2.35 & - & 1.07 \\
\hline
\end{tabular}

\begin{tabular}{|c|c|c|c|c|c|c|c|}
\hline & & \multicolumn{6}{|c|}{ I Including All Intangibles } \\
\hline & & \multicolumn{3}{|c|}{ Value-Added per Hours Worked } & \multicolumn{3}{|c|}{ Total Factor Productivity } \\
\hline & & $\begin{array}{l}\text { Value-Added } \\
\text { Weight }\end{array}$ & $\begin{array}{l}\text { Value-Added } \\
\text { Growth }\end{array}$ & $\begin{array}{l}\text { Contribution } \\
\text { to Aggregate } \\
\text { Value-Added }\end{array}$ & Domar Weight & TFP Growth & $\begin{array}{l}\text { Contribution } \\
\text { to Aggregate } \\
\text { TFP }\end{array}$ \\
\hline 1 & Agriculture, Fishing and Mining & 0.04 & -1.98 & -0.07 & 0.07 & -2.76 & -0.19 \\
\hline 2 & Manufacturing & 0.23 & 4.70 & 1.07 & 0.55 & 0.37 & 0.18 \\
\hline 3 & Electricity, Gas and Water Supply & 0.02 & 2.01 & 0.05 & 0.07 & -0.28 & -0.02 \\
\hline 4 & Construction & 0.08 & 1.44 & 0.12 & 0.19 & -0.13 & -0.02 \\
\hline 5 & $\begin{array}{l}\text { Trade, Hotels and Restaurants, Transport } \\
\text { and Communications }\end{array}$ & 0.32 & 3.05 & 0.96 & 0.58 & 0.32 & 0.18 \\
\hline 6 & $\begin{array}{l}\text { Financial Intermediation and Business } \\
\text { Services }\end{array}$ & 0.31 & 1.97 & 0.61 & 0.56 & -0.17 & -0.08 \\
\hline & Sum & 1.00 & - & 2.74 & 2.02 & - & 0.05 \\
\hline
\end{tabular}

Note: All figures are annual averages. Value-added weights are the share of industry value-added in aggregate value-added. Domar weights are the share of gross output in aggregate value-added. A contribution is defined as the product of the corresponding share and the growth rate. Panel entitled "excluding software" excludes software and other intangibles, other panel includes software and all intangibles. 
Table 9: Innovation Index, 2000-2005

\begin{tabular}{|c|c|c|c|c|}
\hline & & $\begin{array}{l}\text { Contribution of } \\
\text { Intangible } \\
\text { Capital } \\
\text { Deepening } \\
\end{array}$ & $\begin{array}{l}\text { Contribution of } \\
\text { Aggregate TFP }\end{array}$ & Total \\
\hline & All industries & 1.19 & 0.05 & 1.24 \\
\hline 1 & Agriculture, Fishing and Mining & 0.01 & -0.19 & -0.18 \\
\hline 2 & Manufacturing & 0.54 & 0.18 & 0.72 \\
\hline 3 & Electricity, Gas and Water Supply & 0.02 & -0.02 & 0.00 \\
\hline 4 & Construction & 0.08 & -0.02 & 0.06 \\
\hline 5 & Trade, Hotels \& Rest., Transport \& Comm. & 0.29 & 0.18 & 0.47 \\
\hline \multirow[t]{2}{*}{6} & Financial Intermediation and Business Services & 0.25 & -0.08 & 0.17 \\
\hline & $\%$ of column totals & & & \\
\hline 1 & Agriculture, Fishing and Mining & $1 \%$ & & $-15 \%$ \\
\hline 2 & Manufacturing & $45 \%$ & & $58 \%$ \\
\hline 3 & Electricity, Gas and Water Supply & $2 \%$ & & $0 \%$ \\
\hline 4 & Construction & $7 \%$ & & $5 \%$ \\
\hline 5 & Trade, Hotels \& Rest., Transport \& Comm. & $24 \%$ & & $38 \%$ \\
\hline 6 & Financial Intermediation and Business Services & $21 \%$ & & $14 \%$ \\
\hline 6 & Total & $100 \%$ & & $100 \%$ \\
\hline
\end{tabular}

Notes: upper panel is in \% pa, 2000-2005. Lower panel is fraction of the first row. Data are not reported for lower panel TFP fractions since some numbers are negative. For additional role of labour composition deepening, see text. 